\title{
Stock Liquidity, Corporate Governance and Leverage: New Panel Evidence
}

\author{
Nadarajah Sivathaasan ${ }^{\mathrm{a}, 1}$, Searat Ali ${ }^{\mathrm{b}, 1}$, Benjamin $\mathrm{Liu}^{\mathrm{c}}$, and Allen Haung ${ }^{\mathrm{d}}$ \\ ${ }^{a, b, c, d}$ Department of Accounting, Finance and Economics, Griffith Business School, Griffith \\ University, Australia.
}

\begin{abstract}
We examine the effect of stock liquidity and corporate governance on the firm's leverage decision in the order-driven stock trading system and less stringent governance environment of Australia. Using a sample of 1,207 non-financial firms from 2001 to 2013, resulting in 9,855 firm-year observations, we find the posited negative stock liquidity-leverage relation, confirming prior research observations that firms with more liquid stocks are significantly less leveraged. We also find a significant and negative relation between corporate governance quality (CGQ) and leverage, indicating that firms with high CGQ significantly reduce leverage. In a closer analysis, we find that the significantly negative CGQ-leverage relation exists only for firms with high stock liquidity and does not exist for firms with low stock liquidity. Our study is the first to examine such an interactive relationship among stock liquidity, corporate governance and leverage. The results, which are robust to a range of alternative proxies and to additional tests, provide new insights into the determinants of leverage.
\end{abstract}

Keywords: stock liquidity, corporate governance quality, leverage, Australia

JEL classification: G12, G32, G34

\footnotetext{
${ }^{1}$ Corresponding authors: Nadarajah Sivathaasan (sivathaasan.nadarajah@griffithuni.edu.au) and Searat Ali (searat.ali@griffithuni.edu.au), Department of Accounting Finance and Economics, Griffith Business School, Griffith University, 170 Kessels Road, Nathan QLD 4111, Australia. Tel.: +61 737353903.
}

\section{Acknowledgements}

We thank Barry Williams (the guest editor) and two anonymous reviewers for their insightful comments and suggestions to improve the quality of our paper. In the early stage of developing this research idea, our thinking was greatly assisted by completing the "pitching template” created by Faff (2015, 2016). We thank Robert Faff, Zoltan Matolscy, Karen Benson, Gary Monroe, Dave Michayluk, Eliza Wu, Haralc Scheule, and the participants for their helpful comments at the SIRCA's pitching research symposium, University of Technology Sydney, Sydney, 2016. We are also thankful to United Overseas Resources Ltd (Hong Kong) for the financial support, Griffith University Postgraduate Students Association (GUPSA) for the write-up assistance and the SIRCA for the symposium travel grant. 


\section{Introduction}

Despite over half a century of research effort since the pioneering work of Modigliani and Miller (1958), the debate on how managers make capital structure (i.e., leverage) decisions remains one of the most challenging issues in the corporate finance literature (Andres et al., 2014; Jiraporn et al., 2012). Given the imperfection of the capital market in the real world, the decision - the choice between how much debt and how much equity managers use in financing firms’ investments-is an important one because an optimal capital structure can maximize firm value by minimizing the cost of capital. Clayman et al. (2012) argue that defining at which level of debt financing a firm reaches its optimal capital structure is difficult because this depends mainly on the firm's stock liquidity (i.e., asymmetric information) and corporate governance. Prior studies have investigated the relation between stock liquidity and leverage (e.g., Lipson and Mortal, 2009) and the relation between corporate governance and leverage (e.g., Jiraporn et al., 2012). However, these two relations have only been examined separately: No research has yet examined the two relations simultaneously. This study investigates the joint effect of stock liquidity and corporate governance on leverage, particularly in the Australian context, with its unique stock trading mechanism and corporate governance environment that affect a firm's stock liquidity and corporate governance practices, respectively.

Theories of capital structure (i.e., the static trade-off and pecking-order theories) predict a similar relationship between stock liquidity and leverage. According to the static trade-off theory, a firm with more liquid stock has a lower flotation cost for equity issuance, which makes the equity financing more attractive than debt financing. Thus, firms with more liquid stocks are expected to have a lower leverage. A few empirical studies have paid attention to stock liquidity as a critical determinant of leverage across the globe. Lipson and Mortal (2009) and Udomsirikul et al. (2011) document a negative relation between stock liquidity and leverage in the US and Thailand, respectively; Mohamed and Seelanatha (2014) find a 
significant (insignificant) negative relation between liquidity and leverage in the pre-GFC (post-GFC) periods for Australian firms. However, the study by Mohamed and Seelanatha (2014) has methodological limitations (e.g., small sample size, limited liquidity proxies, inadequate estimation methods, and endogeneity bias) which are overcome in our study.

The findings on the stock liquidity-leverage relation from other countries, particularly the US, may not be direcly applicable to the Australian market because of the differences in the stock trading mechanisms in the two countries. Whereas the US has a quote-driven stock trading mechanism, Australia has a pure order-driven trading system with the absence of market markers (Chai et al., 2010). In a quote-driven market, designated market makers continuously quote the bid and ask prices, which provides liquidity (Ali et al., 2015). In an order-driven market, public-limit orders establish the bid and ask prices and provide liquidity to the market (Chai et al., 2010). Evidence shows that the order-driven trading mechanism results in higher stock liquidity than the quote-driven system (Brown and Zhang, 1997). It is, therefore, interesting to know how stock liquidity affects leverage in an order-driven market. Given the increased use of the order-driven trading mechanism around the globe in recent years (Chai et al., 2010), we are motivated to investigate the stock liquidity-leverage relation, in conjunction with the corporate governance and leverage relation, within the order-driven Australian context.

According to the agency theory, firms can use debt as a monitoring mechanism alternative to corporate governance for alleviating the agency problem between managers and shareholders. The use of debt forces managers to make better investment decisions. So firms with poor governance are expected to have a higher leverage. Consistent with this theoretical argument, prior empirical studies articulate an inverse relationship between corporate governance quality (CGQ), by using a composite CGQ index that aggregates individual corporate governance variables, and leverage outside Australia (e.g., Haque et al., 2011; Jiraporn and Gleason, 2007; Jiraporn et al., 2012). For instance, Jiraporn et al. (2012), using a 
composite CGQ index, find that a high CGQ reduces leverage. Australian studies (e.g., Brailsford et al., 2002; Yarram, 2013a, 2013b) narrowly examine the effect of individual governance variables (e.g., ownership structure, board structure and CEO duality) on leverage and find inconclusive or incomprehensive results. Yarram (2013a) finds that the proportion of independent directors, CEO duality and board meetings reduce leverage, whereas board skills, experience and board meeting attendance have no significant relationship with leverage. No research yet explores the impact of an aggregate index-based CGQ on leverage for Australian firms. From a wider regulatory perspective, research using index-based CGQ is needed to provide support for the development of a comprehensive code of governance practice, as opposed to the adoption of individual governance practices.

The composite CGQ-leverage findings from other countries, particularly the US, may not be direcly applicable to Australia because of its markedly different corporate governance setting (Dignam and Galanis, 2004; Khan et al., 2014). The corporate governance system in the US, the outsider system, is characterised by a securities market with dispersed shareholdings where shareholders and firms interact at arms' length, largely determined by the market forces. In the Australian corporate governance system, the insider system, with more concentrated shareholdings the roles of banks, families and non-financial corporate owners are crucial in corporate control (Dignam and Galanis, 2004). As the corporate governance environment in Australia is said to be less stringent than that of the US (Mendez et al., 2015), more cross-sectional variation in the governance practices of Australian firms is expected. Given such differences, we are motivated to investigate the composite CGQleverage relation for Australian firms, which operate on the insider system, in conjunction with the stock liquidity and leverage relation.

Extant studies examine the stock liquidity-leverage relation and the CGQ-leverage relation separately. To our best knowledge, no research to date has examined how stock liquidity and CGQ jointly influence leverage. On the one hand, better corporate governance is 
believed to improve stock liquidity by improving the informational transparency of a firm (e.g., Ali et al., 2016; Chung et al., 2010). On the other hand, enhanced stock liquidity leads to less use of debt and more use of equity in the capital structure due to the reduced cost of equity (e.g., Lipson and Mortal, 2009; Udomsirikul et al., 2011). Combining these two strands of literature suggests that better corporate governance improves stock liquidity, and improved stock liquidity ultimately reduces leverage. Instead we posit that the inverse effect of corporate governance on leverage should be stronger for firms with greater stock liquidity. These ideas indicate the necessity of investigating how both stock liquidity in the order-driven market and CGQ in the insider governance system influence the leverage in Australia. In this study, we therefore aim to answer three key questions: 1 . Do firms with higher stock liquidity experience a lower level of leverage? 2. Does corporate governance inversely relate to a firm's leverage? 3. Is the negative relationship between corporate governance and leverage stronger for firms with high stock liquidity than for firms with low stock liquidity?

We use a large sample of 1,207 non-financial Australian firms over the period from 2001 to 2013, resulting in 9,855 firm-year observations. We use three proxies for stock liquidity, namely, time-weighted quoted spread (QS), Amihud illiquidity estimate (Amihud) and turnover-adjusted zero daily volumes (LM), which capture three different dimensions of liquidity respectively: trading cost, price impact and immediacy. We measure corporate governance by adopting recommendations of the Horwath Report to construct a composite CGQ index. The Horwath Report is comprehensive and well recognized in the research community. Unlike the well-renowned US based governance index (G-index) of Gompers et al. (2003), which focuses on the resistance of firms to external control mechanisms, the Horwath Report places emphasis on the quality of a firm's internal structures and processes (e.g., board structure, audit committee, remuneration committee and nomination committee), which are better suited to the Australian corporate control practices. Finally, we define leverage by using both book and market values of the firm. 
Our fixed effect (FE) regression analysis shows that stock liquidity negatively affects leverage, suggesting that firms with higher stock liquidity exhibit a lower level of debt in their capital structure. We also find a negative relationship between CGQ and leverage, indicating that firms with high CGQ significantly reduce leverage. This relationship is stronger when we use market leverage, implying that firms can use higher leverage as a substitute for weaker governance mechanisms. In a closer analysis, we observe an interactive relationship among stock liquidity, CGQ and leverage: the results show that the significantly negative CGQleverage relation exists only for firms with high stock liquidity; and it does not exist for firms with low stock liquidity. This interactive relationship provides empirical evidence that shows the effect of a high CGQ on lowering leverage prevails in highly liquid firms in the Australian context. This suggests that firms with low stock liquidity should achieve high standards of corporate governance to reduce leverage. The results are statistically significant, economically meaningful, and robust to a range of alternative proxies, to additional tests, and to endogeneity bias.

The findings of our study contribute to three strands of corporate finance literature. First, while prior studies have well documented the stock liquidity-leverage relation (e.g., Lipson and Mortal, 2009) and the CGQ-leverage relation (e.g., Jiraporn et al., 2012), there has been no prior research that examines the two relations simultaneously, although it is alleged that a firm’s leverage decision mainly depends on its stock liquidity and corporate governance (e.g., Clayman et al., 2012). Furthermore, a recent study (i.e., Ali et al., 2016) provides evidence that shows a positive relation between CGQ and stock liquidity. Despite the evidence that stock liquidity, corporate governance and leverage are related, and despite the theoretical prediction among them, how stock liquidity and corporate governance jointly determine firms’ leverage is largely unknown to us. Our study fills this knowledge gap. As far as we know, our study is the first globally that examines the interactions among market microstructure (i.e., stock liquidity), corporate governance and corporate finance (i.e., 
leverage) in a single study. In particular, we document robust evidence that shows the negative relation between corporate governance and leverage is stronger and significant only for high liquidity firms.

Second, our study contributes to the empirical literature on the relationship between stock liquidity and leverage in the order-driven market of Australia. In particular, we address the methodological limitations associated with the earlier Australian study by Mohamed and Seelanatha (2014), which focuses mainly on the liquidity proxies constructed from low frequency data (i.e., Amihud and turnover) using a sample that excludes small firms although small firms consist of a substantial proportion of all listed firms in the Australian market (Christensen et al., 2015). In contrast, we extend the literature by incorporating proxies from both high frequency data (i.e., time-weighted quoted spread) and low frequency data (e.g., turnover-adjusted zero daily volumes) using a large panel dataset from 2001 to 2013. Hence, our findings may be generalizable to those wider markets using both microstructure and daily $\operatorname{data}^{2}$ and to all firm sizes (large, medium and small). Moreover, unlike their study, we improve understanding of the potential endogenous relation between liquidity and leverage, mainly by employing an exogenous shock to liquidity, which is a market microstructure shock unique to Australia, and our findings provide a certain extent of comfort that causality runs from liquidity to leverage.

Third, our study contributes to the empirical literature on the relationship between corporate governance and leverage in the less stringent governance environment of Australia. Existing Australian studies document evidence of the CGQ-leverage relation, based on individual governance variables (e.g., Brailsford et al., 2002; Yarram, 2013a, 2013b) and using a short panel dataset (i.e., 49 firms during 1989-1995; 465 firms during 2004-2010 and 153 firms during 2004-2010, respectively). We provide the index-based evidence on the corporate governance-leverage relation, which may support the development of a

\footnotetext{
${ }^{2}$ Microstructure data on transactions and quotes are required to calculate high frequency liquidity proxies whereas daily data on returns and volume are required for low frequency liquidity proxies (Ali et al., 2015).
} 
comprehensive code of governance practices rather than individual governance practices.

The reminder of our study is as follows. Section 2 discusses the relevant prior studies, theoretical background and hypotheses. Section 3 describes the data and method we use in the study. Section 4 explores the empirical findings of our study. Section 5 concludes the study.

\section{Literature review and hypothesis development}

\subsection{Stock liquidity and leverage}

Stock liquidity and leverage are two different types of decisions. Stock liquidity—a major concern for those who trade shares and those who create, manage or regulate trading infrastructure (Lipson and Mortal, 2009) —is made by the market participants. The leverage decision-one of the most important decisions in the corporate finance (e.g., Bhatia et al., 2015; Jiraporn et al., 2012) —is made by the firms. These two decision types have different determining factors and, hence, different theoretical underpinnings.

The static trade-off and the pecking-order theories have been used to explain the leverage decision and to predict a similar relationship between stock liquidity and leverage. The static trade-off theory, developed by Modigliani and Miller (1958), suggests that firms trade off the net cost of equity against the net cost of debt when raising capital (e.g., Clayman et al., 2012; Lipson and Mortal, 2009). According to this theory, firms with more liquid stocks have a lower flotation cost for equity issuance that makes equity financing more attractive. For instance, Amihud and Mendelson (1986) document that enhanced firms’ stock liquidity lowers the cost of equity, resulting in a lower use of debt in the capital structure. Andres et al. (2014) also show that stock liquidity has a direct effect on equity returns, on the cost of capital and, thus, on shareholder value. Conversely, illiquidity is associated with a higher cost of equity capital (Frieder and Martell, 2006). Prior studies show that equity holders seek compensation by requiring a higher return for bearing costs of illiquidity (e.g., Brennan et al., 1998; Brennan and Subrahmanyam, 1996). Stoll and Whaley (1983) also claim that small stocks that are illiquid are expected to produce a higher rate of return due to higher transaction 
costs. Consequently, equity financing for firms with illiquid stocks becomes more expensive and, thus, less attractive than debt financing, leading to higher leverage.

The pecking-order theory, developed by Myers and Majluf (1984), suggests that firms choose methods for financing according to a hierarchy due to adverse selection and issue debt when internal financing is inadequate (Clayman et al., 2012). The adverse selection conditions that drive the pecking-order preferences (i.e., internal financing, debt financing and equity financing) may be reflected in trading costs to the extent that asymmetry between market participants is correlated with asymmetry between managers and the market (Lipson and Mortal, 2009). All firms have a certain level of asymmetric information, issuing more debt over equity when there is a high asymmetry in information (i.e., less liquidity) (Andres et al., 2014).

A few studies offer empirical evidence on this theoretical prediction of the stock liquidity to leverage relation. For example, Frieder and Martell (2006), using a panel of all firms listed on the New York Stock Exchange (NYSE), find that higher liquidity is associated with lower leverage. Using similar US data, Lipson and Mortal (2009) document that firms with more liquid equity use less debt and prefer equity when raising outside capital. However, the findings of those two US studies may not be directly generalizable to the Australian market due to the different trading mechanism used in Australia. Similarly, Udomsirikul et al. (2011), using firms listed on the Stock Exchange of Thailand (SET), report that firms enjoying more liquid equity experience a lower cost of equity and may be motivated to adopt more equity and less debt in their capital structure. Findings of emerging markets like Thailand may also not be extendable to other countries like Australia, where financial markets are welldeveloped and sophisticated.

In contrast to those studies, the Australian studies report evidence from a microstructure point of view of the effect of liquidity on different aspects; namely, stock returns (Beedles et al., 1988); commonality in liquidity (Fabre and Frino, 2004); the role of closing call auctions 
on liquidity (Aitken et al., 2005); and asset-pricing (Chan and Faff, 2003; Limkriangkrai et al., 2008). An exemption is the study by Mohamed and Seelanatha (2014), addressing a negative relation between stock liquidity and leverage. The findings of their study may not be generalizable to the wider economy because they exclude small firms from the analysis, even though small firms make up a substantial proportion of all listed firms in the financial markets of Australia and most other jurisdictions (Christensen et al., 2015). Their study, limited to the use of low-frequency proxies of stock liquidity, is characterized by a relatively small sample: they employ only two proxies of stock liquidity and use only 4,913 firm-year observations.

Our argument, based on such theoretical predications and coupled with empirical evidence, is that firms with higher stock liquidity (due to either lower cost of equity or less asymmetry in information) lower the use of debt, which leads us to the following hypothesis.

H1. Firms with higher stock liquidity experience a lower level of leverage.

\subsection{Corporate governance and leverage}

Agency theory analyses the relationship between shareholders (i.e., principals) and managers (i.e., agents), alleging that the rise of agency problems stems from the conflicts of interest between them (Clayman et al., 2012). To control such agency problems, internal and external mechanisms in the context of a corporation are necessary (McColgan, 2001). Corporate governance (internal mechanism) and leverage (external mechanism) can be substituted for each other in alleviating agency conflicts. Jensen and Meckling (1976) are the first to argue that the agency conflicts between managers and shareholders are related to capital structure decisions (Bhatia et al., 2015). In particular, agency theory designs debt as an alternative governance mechanism to mitigate agency conflicts (e.g., Jensen and Meckling, 1976; Jiraporn et al., 2012; Kochhar, 1996). It predicts a reduction in the net agency costs of equity resulting from increased use of debt (Clayman et al., 2012) because an increase in debt (i.e., higher leverage) motivates managers to use firms’ assets more efficiently, as they are bound to pay interest and repay principal. 
As for the disciplinary role of leverage, corporate governance mechanisms provide monitoring of managers to protect shareholders (Christensen et al., 2015; Shleifer and Vishny, 1997). Good governance practices mean that the managers' interests are better aligned with those of shareholders, leading to lower agency costs and higher shareholder value (Clayman et al., 2012). Conversely, firms with weak corporate governance suffer more severe agency problems, resulting in higher agency costs (Jiraporn et al., 2012). Gompers et al. (2003) also argue that the improved corporate governance and strong shareholder rights reduce related agency costs and improve investor confidence in firms' future cash flow. Consequently, the firms' ability to gain access to equity financing improves and reliance on debt financing is reduced (Drobetz et al., 2004; Haque et al., 2011). The substituting roles of corporate governance and leverage in alleviating the agency conflicts indicate an inverse relation between them.

Prior studies have mainly employed US data to explore the nexus between corporate governance and leverage. Jiraporn and Gleason (2007), using the G-index, report an inverse relation between corporate governance and leverage, suggesting that firms adopt higher debt ratios where shareholder rights are more restricted. Similarly, Jiraporn et al. (2012), using the composite corporate governance scores from the Institutional Shareholder Services (ISS), find that corporate governance reduces leverage, suggesting that corporate governance and leverage are substitutes to each other in mitigating the agency conflicts.

As opposed to the index-based evidence on the CGQ-leverage relation, Australian studies employ individual governance variables (e.g., ownership structure, board structure and CEO duality) to examine their effects on leverage. For example, using a small cross-sectional dataset (i.e., 49 firms) during the 1989-1995 period, Brailsford et al. (2002) examine the relation between ownership structure and leverage and find that firms with high ownership concentration hold a relatively high leverage, while the relation between managerial ownership and leverage is non-linear. Yarram (2013b) also finds evidence in favour of a 
positive relation between ownership concentration and leverage for a sample of 465 firms during 2004-2010. Applying similar time-series to 153 large firms, Yarram (2013a) finds that the proportion of independent directors, the CEO duality and the board meetings reduce leverage, whereas board skills, experience and board meeting attendance have no significant relation to leverage. There has been no study in Australia that examines the CGQ-leverage relation using a composite CGQ index embracing individual governance variables, which is supposedly a better measure of corporate governance quality.

Given the substituting roles of corporate governance and leverage in resolving the agency conflicts, we posit the following hypothesis.

H2. Corporate governance quality (CGQ) of a firm is inversely related to the firm's leverage.

\subsection{Stock liquidity, corporate governance and leverage}

Corporate governance provides monitoring mechanisms on managers. Better governed firms disclose more and better quality information to the market in a timely way, which improves firms’ financial and operational transparency. For instance, Beekes et al. (2015) show that better, compared to poorer, governed firms are priced more efficiently (i.e., news is priced earlier) in equity markets and can signal their quality by being more conservative relating to reporting good news. Ali et al. (2015) report that good corporate governance can prevent opportunistic managers from concealing and distorting information. Greater and better disclosure of information to the market has the effect of alleviating information asymmetries between insiders (i.e., managers) and outside investors, as well as among the outside investors (e.g., Chung et al., 2010; Millicent et al., 2008; Welker, 1995). This reduction in information asymmetries enhances firms' stock liquidity and lowers firms' cost of equity capital, resulting in lower leverage (Amihud and Mendelson, 1986).

Prior studies from the US (Chung et al., 2010) and Australia (Ali et al., 2015) report evidence of a positive relation between corporate governance and stock liquidity. Such studies 
have examined the stock liquidity-leverage relation (e.g., Frieder and Martell, 2006; Lipson and Mortal, 2009) and the CGQ-leverage relation (e.g., Jiraporn and Gleason, 2007; Jiraporn et al., 2012) separately. However, as noted no research has yet examined the interactive relationship among stock liquidity, CGQ and leverage. We argue that firms with less liquid stocks and firms with more liquid stocks may observe different interactions among these parameters, as these different firms do not have the same level of transaction costs. Prior studies show that small firms' stocks with less liquidity cause a high level of transaction costs (Stoll and Whaley, 1983) and may be expected to produce a higher rate of return. We therefore assume that the relation between CGQ and leverage is dependent on firms' stock liquidity and postulate the following hypothesis.

H3. The inverse relation between CGQ and leverage is stronger for firms with higher stock liquidity than for firms with lower stock liquidity.

\section{Data and Methodology}

\subsection{Sample}

The primary source of data is that of Australian firms listed on Australian Securities Exchange (ASX) during the period from 2001 to 2013. To construct our sample, we use the Securities Industry Research Centre of Asia-Pacific database (SIRCA), which provides corporate governance and stock liquidity (e.g., share price and trading volume) data from 2001. We retrieve financial data perfected by the firms' annual reports from the Morningstar DatAnalysis Premium database. We initially obtain a raw sample of 13,500 firm-year observations from these databases. Following conventional practices (Chang et al., 2014), we exclude 3,321 firm-year observations from financial firms as they are subject to unique financial characteristics and operating regulations. We further exclude 324 firm-year observations due to missing data. The final sample comprises 1,207 non-financial firms, with 9,855 firm-year observations. These sample firms belong to nine GICS sectors-materials (33\%), industrials (16\%), health care (9\%), telecommunications services (2\%), consumer 
staples (4\%), consumer discretionary (14\%), information technology (7\%), energy (13\%) and utility (1\%). Following Dang (2013) and Faulkender and Petersen (2006), we winsorize all continuous variables at the 1st and 99th percentiles to mitigate the potential effects of extreme values.

\subsection{Variable definition and measurement}

\subsubsection{Dependent variable: leverage proxies}

Previous studies adopt both book and market values to estimate a firm's leverage (e.g., Chang et al., 2014; Gaud et al., 2005). In this study, we employ two definitions of leverage using book and market values. Prior studies continue to employ book leverage as a measure in both the Australian (e.g., Cassar and Holmes, 2003; Khan et al., 2014) and the US settings (e.g., Agha, 2013; Jiraporn and Gleason, 2007; Jiraporn et al., 2012; Strebulaev and Yang, 2013), as this proxy largely depends on existing assets in place rather than on growth opportunities (Agha, 2013; Graham and Harvey, 2001; Myers, 1977). To be consistent with prior empirical work, we use the ratio of total debt to book value of assets as a proxy for book leverage (BL).

$B L_{i, t}=\frac{S T D_{i, t}+L T D_{i, t}}{T A_{i, t}}$

Where $B L_{i, t}$ denotes the book leverage ratio of firm $i$ in year $t, S T D_{i, t}$ is the amount of shortterm debt in current liabilities, $L T D_{i, t}$ is the amount of long-term debt exceeding maturity of one year and $T A_{i, t}$ is the book value of assets.

Following prior studies (e.g., Chang et al., 2014; Fan et al., 2012; Jiraporn et al., 2012; Liao et al., 2015), we define market leverage (ML) as the ratio of total debt to market value of assets where market value of assets is the sum of book value of short-term debt and long-term debt plus market value of equity.

$M L_{i, t}=\frac{S T D_{i, t}+L T D_{i, t}}{S T D_{i, t}+L T D_{i, t}+M V E_{i, t}}$

Where $M L_{i, t}$ denotes the market leverage ratio of firm $i$ in year $t, M V E_{i, t}$ is the common 
shares outstanding multiplied by the price of the last trading day (Lipson and Mortal, 2009) and other parameters are identical to those used in equation (1).

\subsubsection{Independent variables}

\subsubsection{Stock liquidity proxies}

We proxy stock liquidity encompassing three dimensions, trading cost, price impact and immediacy, following prior studies (e.g., Ali et al., 2016; Chai et al., 2010; Udomsirikul et al., 2011). The time-weighted quoted spread (QS) captures trading cost; Amihud illiquidity estimate (Amihud) and the turnover-adjusted zero daily volumes (LM) capture the price impact of trade and immediacy, respectively.

First, we define the time-weighted quoted spread (QS) as the daily ratio of the timeweighted bid-ask spread divided by the time-weighted mid-point spread averaged over the number of trading days in a financial year. This measure of QS is similar to the measure used by Aitken and Frino (1996) and Millicent et al. (2008): the higher the QS, the lower the stock liquidity.

${\text { Quoted } \text { spread }_{i y}=\frac{1}{D_{i y}} \sum_{d=1}^{D_{i y}} \frac{\text { TWBidAskSpread }}{\text { Tyd }}}_{\text {TWidPointPrice }}^{\text {iyd }}$

Where TWBidAskSpread ${ }^{3}{ }_{\text {iyd }}$ is the time-weighted bid-ask spread of firm $i$ on day $d$ of year $y$, TWMidPointPrice $^{4}{ }_{\text {iyd }}$ is the time-weighted mid-point price of firm $i$ on day $d$ of year $y$, and $D_{i y}$ is the number of days with available data for firm $i$ in year $y$.

Second, we compute Amihud's illiquidity estimate (Amihud) as the daily ratio of absolute stock return to trading volume in Australian dollars, averaged over the number of trading days in a financial year: the higher the Amihud, the lower the stock liquidity.

\footnotetext{
${ }^{3}$ TWBidAskSpread $_{\text {iyd }}=\frac{(\text { Ask-Bid }) \times \text { Time }_{1}+(\text { Ask-Bid }) X \text { Time }_{2}+\ldots+(\text { Ask-Bid }) X \text { Time }_{n}}{\text { Time }_{1}+\text { Time }_{2}+\cdots+\text { Time }_{n}}$

${ }^{4}$ TWMidPointPrice $_{\text {iyd }}=\frac{\frac{(\text { Ask-Bid })}{2} \times \text { Time }_{1}+\frac{(\text { Ask-Bid })}{2} \times \text { Time }_{2}+\ldots+\frac{(A s k-B i d)}{2} \times \text { Time }_{n}}{\text { Time }_{1}+\text { Time }_{2}+\cdots+\text { Time }_{n}}$
} 


$$
\text { Amihud }_{i y}=\frac{1}{D_{i y}} \frac{\sum_{d=1}^{D_{i y}}\left|R_{i y d}\right|}{V O L D_{i y d}}
$$

Where $R_{i y d}$ is the absolute stock return of firm $i$ on day $d$ of year $y, V O L D_{i y d}$ is the trading volume of firm $i$ on day $d$ of year $y$ and $D_{i y}$ is the number of days with available data for firm $i$ in year $y$.

Third, we estimate turnover-adjusted zero daily volumes (LM) to capture multiple dimensions of liquidity: the higher the LM, the lower the stock liquidity.

$L M_{i, t}=\left[N o Z V_{i, t}+\frac{1 /\left(\text { turnover }_{i, t}\right)}{\text { Deflator }}\right] X \frac{252}{\text { NoTD }_{t}}$

Where $\operatorname{NoZV}_{i, t}$ is the number of zero daily trading volumes for firm $i$ in year $t$, turnover $_{i, t}$ is the stock turnover for firm $i$ in year $t$ obtained from the sum of daily shares traded per year to the number of shares outstanding, $N o T D_{t}$ is the total number of trading days in year $t$ and the deflator is set to 480,000 as suggested in Liu (2006). Multiplication by the factor $\frac{252}{\text { NoTD }_{t}}$ standardizes the number of trading days in a year as 252 and therefore makes LM comparable over time.

\subsubsection{Corporate governance proxies}

In this study, we construct a comprehensive measure of the CG index using the Horwath composite ratings on six categories: board structure, audit committee, nomination committee, remuneration committee, external auditor independence and codes of conduct and other policy disclosures. Previous studies on corporate governance use the G-index in the US, which is suitable for their outsider system in the country (e.g., Jiraporn and Gleason, 2007; Jiraporn et al., 2012; Klock et al., 2005). With Australia’s insider system, internal CG mechanisms are more appropriate for measuring CG quality: the market for corporate control as a tool to discipline poorly performing managers is not effective (Pham et al., 2011). We therefore focus on the quality of internal structures and controls of the firms when constructing the composite CGQ index. 
The Horwath report, which aims at the top 250 firms for the period from 2001 to 2008 with the proprietary arrangement of their ratings system (Ali et al., 2015), limits the generalizability of the findings. We overcome this limitation by extending our CG dataset across both cross-sections (small, medium and large firms) and time-series (2001-2013) on the objective categories, following Ali et al. (2015). As these categories consist of 17 criteria, we assign the value " 1 ” if a firm meets the particular criteria and " 0 ” otherwise. For example, on the independence of the board, if the majority of directors in a firm are independent, we assign 1 and 0 otherwise. We aggregate these individual values to construct a composite CG index (ranging from 0 to 17) where 0 indicates the "worst" governance and 17 indicates the "best" governance. Each governance category is the aggregate of the respective individual criteria.

\subsubsection{Control variables}

The choice between debt financing and equity financing by a firm largely depends on the firm-specific factors other than stock liquidity and corporate governance (Clayman et al., 2012). Following previous studies (e.g., Frank and Goyal, 2009; Mohamed and Seelanatha, 2014; Myers, 1977; Smith et al., 2015; Udomsirikul et al., 2011), we control for firm size (Size), tangibility (Tang), growth opportunities (MTB) and firm age (Age), which represent a positive empirical relation with leverage. In line with existing studies (e.g., Deesomsak et al., 2004; Frank and Goyal, 2009; Smith et al., 2015; Udomsirikul et al., 2011), we also include a series of variables that exhibit a negative empirical relation with leverage. For example, we use profitability (ROA), firm risk (Risk), non-debt tax shields (NDTS), asset liquidity (Assetliq), ownership concentration (Top-20) and the reciprocal of share price (STPrice). Finally, we include year effect (YR) in the model to capture possible variation overtime.

Table 1 provides definitions of the dependent, independent and control variables employed in this study.

[INSERT TABLE 1 here] 


\subsection{Empirical models}

We investigate three main issues, stock liquidity, CGQ and leverage, in the Australian context. First, we run the following panel regression (Eq.6) to examine the relation between stock liquidity and leverage (Hypothesis 1).

$$
\begin{aligned}
\text { Leverage }_{i, t}= & \alpha_{0}+\alpha_{1} \text { Stock liquidity }_{i, t}+\sum_{j=1}^{11} \gamma_{j} \text { Control variable }_{j} \text {. }_{i . t} \\
& +u_{i, t}
\end{aligned}
$$

In this model, the dependent variable is leverage, which is measured by book leverage (BL) and market leverage (ML). The independent variable is stock liquidity, which is measured using three different proxies (QS, Amihud and LM). The index $i$ denotes individual firms $(i=1,2, \ldots, 1207), t$ denotes time period $(t=2001,2002, \ldots \ldots ., 2013), \alpha, j, \gamma$ are parameters, $\mathrm{u}_{i, t}$ is the error term and $\alpha_{0}$ is a constant (refer to Table 1 for definitions of variables).

We employ the following panel data model (Eq.7) to examine the relation between corporate governance and leverage (Hypothesis 2).

$$
\begin{aligned}
\text { Leverage }_{i, t}= & \beta_{0}+\beta_{1} \text { CGQ }_{i, t}+\sum_{j=1}^{11} \gamma_{j} \text { Control variable }_{j . t} \\
& +u_{i, t}
\end{aligned}
$$

To measure CGQ, we use a composite CG index, the independent variable of this model. $\beta_{0}$ is a constant and $\beta_{1}$ is the vector of coefficient. The definitions of leverage and control variables, other parameters $(j, \gamma)$, indices and the error term are identical to those used in equation (6).

We investigate the effect of both stock liquidity and corporate governance on leverage (Hypotheses 1 and 2) by formulating the following regression (Eq.8): 


$$
\begin{aligned}
\text { Leverage }_{i, t}= & \delta_{0}+\delta_{1} \text { Stock liquidity }_{i, t}+\delta_{2} \text { CGQ }_{i, t} \\
& +\sum_{j=1}^{11} \gamma_{j} \text { Control variable }_{j . t} \\
& +u_{i, t}
\end{aligned}
$$

In this model, we incorporate stock liquidity and CGQ as independent variables where $\delta_{0}$ is a constant and $\delta_{1 t o 2}$ are the vector of coefficients. The definitions of stock liquidity, CGQ, control variables, other parameters $(j, \gamma)$, indices and the error term are identical to those used in equations (6) and (7).

Finally, to test whether the impact of CGQ on leverage differs between firms with high and low stock liquidity (Hypothesis 3), we estimate the following panel data model (Eq.9):

$$
\begin{aligned}
\text { Leverage }_{i, t}= & \gamma_{0}+\gamma_{1} C G Q_{i, t}+\gamma_{2} C G Q_{i, t} * \text { stock liquidity } \\
& +\sum_{j=1}^{11} \gamma_{j} \text { Control variable }_{j . t} \\
& +u_{i, t}
\end{aligned}
$$

In this model, we incorporate CGQ and the interaction term of CGQ*stock liquidity as independent variables where $\gamma_{0}$ is a constant and $\gamma_{1 \text { to } 2}$ are the vector of coefficients. The definitions of stock liquidity, CGQ, control variables, other parameters $(j, \gamma)$, indices and the error term are identical to those used in equations (6) and (7).

\section{Empirical Results}

\subsection{Descriptive statistics}

Table 2 presents summary statistics for the main proxies of leverage (BL and ML), the stock liquidity (QS, Amihud and LM), corporate governance (CG index) and the firm-specific determinants. The statistics show that the average book and market leverage are $36 \%$ and 27\%, respectively. These values are significantly higher than those in the study of Mohamed and Seelanatha (2014), perhaps due to the much larger and hence more representative samples of our study. The mean value of QS is 0.05 , which exhibits a lower variation compared to other proxies such as Amihud and LM. Among the three proxies of stock liquidity, LM shows 
the largest standard deviation ( $\mathrm{SD}=5.64)$; the $\mathrm{CG}$ index sample mean and standard deviation being 8.46 and 4.54 , respectively.

[INSERT TABLE 2 here]

A few of the detailed statistics for firm-specific determinants, reported in Table 2, are worth highlighting. The ratio of market value to book value (MTB), measuring firms' growth opportunities, is 2.48 on average. The Top-20 averages $63.6 \%$, which indicates a high level of ownership concentration among the twenty largest shareholders, a feature of the Australian market as noted earlier.

\subsection{Stock liquidity-leverage (H1) and corporate governance-leverage relations (H2)}

We determine the stock liquidity-leverage relation (H1) and corporate governanceleverage relation (H2) using the FE regression model ${ }^{5}$. Columns $1-2,3-4$ and 5-6 in Table 3 report the regression results of equation (6) for QS, Amihud and LM, respectively and Columns 7-8 report that of equation (7) for CGQ.

As shown in Table 3 (Columns 1-6), the coefficients of the time-weighted quoted spread (QS), Amihud illiquidity estimate (Amihud) and turnover-adjusted zero daily volumes (LM) are all positive and significant at the $1 \%$ level, regardless of whether book or market leverage is employed. In general, coefficients on trading cost (QS), price impact (Amihud) and immediacy measures (LM) are inverse measures of stock liquidity, that is, high scores indicating low stock liquidity and vice versa (Lipson and Mortal, 2009). Hence, the positive coefficients indicate a negative relation between stock liquidity and leverage, suggesting that more (fewer) liquid firms choose a lower (higher) level of leverage ${ }^{6}$.

\footnotetext{
5 To choose between random effect and fixed effect, this study performs the Hausman test and the untabulated results confirm the appropriateness of the FE estimation.

${ }^{6}$ To provide further support for the effect of stock liquidity on leverage (H1), we also run similar regressions using zero return measure (Zero), liquidity ratio (LR) and stock turnover (TO) as alternative measures of stock liquidity and find that baseline results are robust with few exceptions. Similarly, we use long-term book leverage (LDB) and long-term market leverage (LDM) as alternative measures of leverage and confirm similar results as reported in Table 3.
} 
The coefficients of QS, Amihud and LM are consistent for book and market value measures of leverage, but are larger in magnitude for market value, which is in line with the findings of Mohamed and Seelanatha (2014) and Lipson and Mortal (2009). The explanatory power of Mohamed and Seelanatha (2014)'s model documents a decrease from $40.6 \%$ to 36.3\% when moving from book to market value. But in our study, the model on the stock liquidity-leverage relation shows an increase from 21.9\% to 41.1\% (using Amihud) when shifting from book to market value, attributable to our larger samples and better model estimations.

These results support our hypothesis (H1), that firms with more (fewer) liquid stocks exhibit a lower (higher) level of leverage. The results, which are consistent overall with those of Lipson and Mortal (2009), Udomsirikul et al. (2011) and Mohamed and Seelanatha (2014), confirm the notion that liquid stocks reduce the net cost of equity and, therefore, induce firms to adopt more equity financing, causing less debt in the capital structure. However, our study takes advantage of the Australian order-driven trading mechanism, providing additional evidence of the stock liquidity-leverage relation by incorporating both high- and lowfrequency data.

Columns 7-8 of Table 3 report the results of equation (7) $)^{7,8,9}$ for CGQ-leverage relation

\footnotetext{
${ }^{7}$ To test robustness on the CGQ-leverage relation (H2) for Table 3, we also use board quality index (BOI), audit quality index (AQI), nomination quality index (NQI) and remuneration quality index (RQI) as alternative governance proxies and find that the baseline results are not sensitive. Similarly, we use long-term book leverage (LDB) and long-term market leverage (LDM) as alternative measures of leverage and find a statistically significant negative relationship between CGQ and long-term market leverage (LDM).

${ }^{8}$ Given that adoption of corporate governance mechanisms is likely to be different between small and large firms (Christensen et al., 2015), we also include the size effect on the CGQ-leverage relation (H2) where firms are grouped by market capitalization (top-500 firms or less) and size quintiles [small or large (firm size in quintiles $1-2$ denotes small firms and $4-5$ denotes large firms)]. Both classifications provide similar inferences that a statistically significant relationship exists between CGQ and leverage only in the subsample of top-500 firms or large firms. This may be caused by that large firms have strong governance mechanisms (Agha, 2013).

${ }^{9}$ Though the GFC was not as severe in Australia (Mohamed and Seelanatha, 2014), we also capture the
effect of GFC on the CGQ-leverage relation (H2) and document a significant reduction on this relation after the
GFC. Importantly, we document that CGQ continues to hold its role in reducing leverage even in the post-GFC
} 
for book leverage (BL) and market leverage (ML), respectively. The CG index is negatively and significantly related to book and market leverage at the $10 \%$ and $1 \%$ levels, respectively. More importantly, the significance level of the CGQ-leverage relation strengthens (i.e., from $10 \%$ to $1 \%$ ) when leverage is measured by market value. The model for market leverage achieves a reasonable explanatory power as the adjusted $\mathrm{R}^{2}$ is above $32 \%$.

Our findings show that CGQ is also inversely related to firm leverage, using the composite index of the Australian context with the insider system and a less stringent governance environment, which is in line with our hypothesis (H2) and is consistent with prior empirical studies from the US and Bangladesh (e.g., Haque et al., 2011; Jiraporn and Gleason, 2007; Jiraporn et al., 2012). This result confirms the view that firms with poor governance are significantly more leveraged (Jiraporn et al., 2012). Prior Australian study (Yarram, 2013a), by narrowly examining individual governance variables, find results that are either inconclusive or incomprehensive. Our study, with the advantage of using a comprehensive composite CGQ index, contributes to the extant literature. From a wider regulatory perspective, these index-based findings are supportive of the development of a comprehensive code of governance practice, as opposed to the adoption of individual governance practices.

\subsection{Stock liquidity-CGQ-leverage relation (H1 and H2)}

In the previous sections, we report separately the negative relation between stock liquidity and leverage, and between CGQ and leverage. In this section, we examine the effect of both stock liquidity and CGQ on leverage simultaneously and report the regression results of equation (8) in Table 4. Columns 1-2, 3-4 and 5-6 report the results for QS, Amihud and LM, respectively along with CG index and control variables. The estimated coefficients of QS, Amihud and LM for both book and market values are all positive and significant (at 1\% level). This indicates that firms with improved stock liquidity significantly reduce leverage. CGQ is negatively and significantly (at 1\% level) related to leverage for market value, but is 
insignificant for book leverage. More importantly, the results in Columns 2, 4 and 6 for market leverage report significantly higher adjusted $\mathrm{R}$-square $\left(\mathrm{R}^{2}=34.2 \%, 33.0 \%, 34.9 \%\right.$, respectively, $\mathrm{p}<0.01)$ than the results in Columns 1 , 3 and 5 for book leverage $\left(\mathrm{R}^{2}=12.7 \%\right.$, $11.1 \%, 12.7 \%$, respectively, $\mathrm{p}<0.01$ ). This indicates that our regression equation (8) is wellfitted into the model, representing market leverage rather than book leverage ${ }^{10}$.

\section{[INSERT TABLE 4 here]}

Overall, our findings in Table 4 indicate that firms with improved stock liquidity and high CGQ significantly reduce leverage. It is interesting to compare the coefficients on CG index in Table 3 and Table 4: when stock liquidity is included in the model (equation 8) and the analysis (Table 4), the coefficients of CG index decline substantially, although remaining significant, for market leverage, and become insignificant for book leverage. This implies that stock liquidity is a channel between CGQ and leverage, which is examined in hypothesis 3 (H3).

\subsection{CGQ-leverage relation in firms with high and low stock liquidity (H3)}

To examine whether the impact that CGQ has on leverage differs between firms with high and low stock liquidity, we use the interaction term between stock liquidity and CGQ. Such an analysis is useful for examining if stock liquidity acts as a channel between CGQ and leverage (H3). As the coefficients of liquidity and governance measures move in opposite directions, we expect that the interaction effect of stock liquidity and CGQ on leverage would be contradictory. For example, in the previous sections, we have used three liquidity measures (QS, Amihud and LM) to explore the stock liquidity-leverage relation (H1) and the stock liquidity-CGQ-leverage relation (H1 and H2 together). Unlike the governance measure (i.e., CG index), these liquidity measures move in an opposite direction to stock liquidity, that is, the positive coefficient of these measures (i.e., wider spread) denotes low liquidity; the

\footnotetext{
${ }^{10}$ We also examine the robustness on the stock liquidity-CGQ-leverage relation (H1 and H2) using alternative measures of stock liquidity (Zero, LR and TO) for Table 4 and confirm similar results with few exceptions.
} 
negative coefficient (i.e., narrow spread) denotes high liquidity (Lipson and Mortal, 2009). To be consistent with the direction of governance measure, when we run regression we use stock liquidity as a dummy variable by assigning “ 1 ” for high liquidity and " 0 ” for low liquidity rather than a continuous variable.

\section{[INSERT TABLE 5 here]}

Table 5 reports the regression results of equation (9) and shows that the coefficients on CG index*QS are negative and significant at the 5\% and 1\% levels, respectively (Columns 1-2). Similarly, the coefficients on CG index*Amihud (Columns 3-4) and CG index*LM (Columns 5-6) are all negative and significant at the $1 \%$ level. These results confirm that the relationship between CGQ and leverage is negative and stronger when stock liquidity is high. Furthermore, the coefficients on the CG index can be interpreted as the effect of CGQ on leverage when stock liquidity is low. Although the coefficients on the CG index are negative (in five of the six cases), they are insignificant, suggesting that CGQ does not reduce leverage for the firms with low stock liquidity. The ' $t$ ' values of the interaction terms (CG index*QS, CG index*Amihud and CG index*LM) also report significantly higher values across all the models (Columns 1-6), compared with those of the CG index. Overall, the results indicate that the significantly negative CGQ-leverage relation exists for firms with high stock liquidity only and not for firms with low stock liquidity.

Rather than use a liquidity dummy, we treat stock liquidity in continuous form but reverse the scale of CG index ${ }^{11,12}$ to confirm both variables moving in a similar direction. As shown in Panel A of Table 6, the coefficients on reversed CG index*QS, reversed CG index*Amihud and reversed CG index*LM are positive and statistically significant at the $1 \%$ level. These positive signs indicate that poor governed firms with poor liquidity increase firms' leverage;

\footnotetext{
${ }^{11}$ To reverse the governance measure, we deduct the original value from the addition of both maximum and minimum values of the CG index.

${ }^{12}$ We also reverse the initial liquidity measures to be consistent with the direction of CG index. The results show the negative and significant coefficients on the interaction of stock liquidity and CGQ and confirm that the leverage is lower in firms with better corporate governance and greater stock liquidity.
} 
better governed firms with greater stock liquidity have a significantly lower level of leverage. This is consistent with our baseline results, further confirming hypothesis 3 (H3).

\section{[INSERT TABLE 6 here]}

We apply a method similar to that of Johnson (2003) to explore the inverse effect of corporate governance on leverage for increasing the level of stock liquidity. We analyse the results of leverage regression with a condition that allows the coefficients on the CG index to change across sample quintiles based on stock liquidity. We define the liquidity quintiles in a dummy form: high liquidity firms at the top $40 \%$ liquidity quintiles and the low liquidity firms at the bottom 40\% liquidity quintiles. As shown in Panel B of Table 6, the coefficients on the CG index for the top liquidity quintile are negative and statistically significant at varying levels from $10 \%$ to $1 \%$, indicating that the negative effect of corporate governance on leverage is stronger and significant for high liquidity firms only.

We further examine the impact of CGQ on leverage for firms with high and low stock liquidity. If values of QS, Amihud and LM are lower than the median, they represent high liquid firms; otherwise low liquid firms. We report the regression results of equation (9) in Table 7. Columns 1-4, 5-8 and 9-12 indicate the results derived from the proxies of stock liquidity (QS, Amihud and LM, respectively) ${ }^{13}$. The results show that a statistically significant negative relationship between CGQ and leverage (either BL or ML) exists in high liquidity firms (significant in five of the six cases).

\section{[INSERT TABLE 7 here]}

Overall, the results confirm that the significantly negative CGQ-leverage relation exists only for firms with high stock liquidity and not for firms with low stock liquidity, which is in line with hypothesis 3 (H3).

\footnotetext{
${ }^{13}$ We also use alternative measures of stock liquidity (Zero, LR and TO) and leverage (LDB and LDM) to investigate the robustness on the CGQ-leverage relation in firms with high and low liquidity (H3) and find qualitatively similar results as reported in Table 7.
} 


\subsection{Analysis of economic significance}

Table 8 reports the analysis of economic significance of the stock liquidity-leverage relation in Panel A, Panel B and Panel C, of the CGQ-leverage relation in Panel D, and of the interaction effect of stock liquidity and CGQ on leverage in Panel E, Panel F and Panel G. We measure the effect of stock liquidity on leverage by calculating the marginal effect of an increase from the 25th to the 75th percentile and then multiply the difference by the coefficient, yielding a change in the leverage.

The results show that an increase in the time-weighted quoted spread (QS), the Amihud illiquidity estimate (Amihud) and the turnover-adjusted zero daily volumes (LM) mitigates the decline in the book leverage by $10.9 \%, 6.5 \%$ and $11.6 \%$ and in market leverage by $15.0 \%$, $15.9 \%$ and $19.9 \%$, respectively. However, the effect of stock liquidity on leverage is much stronger in the context of market value.

[INSERT TABLE 8 here]

We observe similar patterns for the effect of CGQ on leverage. For instance, an increase in the CG index reduces the book leverage by $3.5 \%$ and the market leverage by $88.1 \%$ approximately. However, the economic significance on the CGQ-leverage is much stronger when leverage is measured by market value. We find similar results for the interaction effect of stock liquidity and CGQ on leverage. An increase in the interaction term (Index*QS, Index*Amihud and Index*LM) lessens the book leverage (3.0\%, 6.1\% and 6.1\%, respectively) and the market leverage (8.1\%, 12.2\% and $12.2 \%$, respectively). Overall, the economic significance for both the stock liquidity-leverage relation and the CGQ-leverage relation is much stronger where leverage is measured by market value.

\subsection{Endogeneity}

Corporate finance research, which attempts to explain the causes and effects of financial decisions, often has serious issues with endogeneity (Wintoki et al., 2012). We address the 
endogeneity issue in the stock liquidity-leverage relation (H1). Though stock liquidity affects leverage, the leverage to liquidity relationship may be endogenous. This may be consistent with the notion that debt forces managers to make better investment decisions (Jensen, 1986), and that managers also consider a potentially detrimental effect of illiquidity on firm value when making leverage decisions (e.g., Amihud and Mendelson, 1989; Andres et al., 2014). A few prior studies provide argument on the direction of causality running from leverage to liquidity. Frieder and Martell (2006) analyse the bi-directional relationship between leverage and liquidity and find that leverage influences liquidity, that is, as leverage increases, spreads decrease (liquidity increases). This finding is consistent with the idea put forth by Amihud and Mendelson (1989) that managers' capital structure decisions reflect their concern that illiquidity reduces value. Similarly, Andres et al. (2014) argue that any change in capital structure has a feedback effect on information asymmetries between managers and outsiders and has a significant impact on liquidity, supporting the signalling hypothesis of Ross (1977). Furthermore, Ali et al. (2016), using Australian firms over the period from 2001 to 2008, document that leverage as a control variable causes stock liquidity.

To rule out the possible endogeneity on the stock liquidity-leverage relation (H1) (either liquidity causes leverage or leverage causes liquidity), we apply an exogenous shock to liquidity, a method similar to that of Nguyen et al. (2016). We use the switch to broker anonymity implemented by the ASX on 28 November 2005 as an exogenous shock to liquidity. Prior to that date, broker ID of each order used to be disclosed in real time to the broker community and after the date, brokers can no longer observe the ID of other brokers submitting orders in the ASX (Nguyen et al., 2016). Therefore, we examine the change in firm's leverage caused by the exogenous shock of the switch to broker anonymity to identify a causal effect of liquidity on leverage. In particular, we regress the change in firm's leverage surrounding the switch against the change in liquidity from the financial year prior to the switch and the financial year after the switch (i.e., from 2004 to 2006) using following 
specification (Fang et al., 2009).

$$
\begin{aligned}
& \Delta(\text { Leverage })_{i, 04 \text { to } 06} \alpha_{0}+\alpha_{1} \Delta(\text { Stock liquidity })_{i, 04 \text { to } 06} \\
& +\sum_{j=1}^{11} \gamma_{j} \Delta(\text { Control variable })_{i .04 \text { to } 06}+u_{i, 04 \text { to } 06}
\end{aligned}
$$

\section{[INSERT TABLE 9 here]}

Table 9 shows similar results for all proxies of stock liquidity (i.e., QS, Amihud and LM). Specifically, the positive coefficients on QS, Amihud and LM in the regressions for $\triangle \mathrm{BL}$ and $\Delta \mathrm{ML}$ indicate an inverse relationship between stock liquidity and leverage. Overall, the results reinforce the findings as reported in the baseline regression and confirm the causality from liquidity to leverage.

To further check the causal effect from liquidity to leverage, we employ the dynamic twostep system GMM to help incorporate all available in the cross-section and time series (Carstensen and Toubal, 2004). These estimates are robust to unobserved heterogeneity, reverse causality and dynamic endogeneity (if any) (Pathan, 2009). As in Columns 1-6 of Table 10, the residuals in the first difference (AR1) are statistically significant at the $1 \%$ level for all models but in the second difference (AR2) are insignificant as expected. Similarly, the Hansen J-statistics of over-identifying restrictions show insignificant statistics for all measures, which indicates the validity of the instruments. Finally, the number of instruments (i.e., 849) used in the models (1-6) is less than the panel (i.e., 1150), which makes the Hansen J-statistics more reliable. The results qualitatively remain similar to those reported earlier in a static setting. For instance, the statistically significant positive coefficients on QS, Amihud and LM on the stock liquidity-leverage relation suggest that firms with more liquid stocks experience a lower level of leverage.

[INSERT TABLE 10 here]

Similarly, we explore the issue of possible endogeneity on the CGQ-leverage relation 
(H2). Prior empirical research suggests that corporate governance drives leverage (e.g., Jiraporn and Gleason, 2007; Jiraporn et al., 2012; John and Litov, 2010), but this may be plagued with endogeneity issues. We often cannot ascertain if the causation is actually reversed, that is, leverage drives corporate governance. However, direction of causality from leverage to corporate governance is less possible for two reasons as argued by Jiraporn et al. (2012). First, it is rather difficult for managers to modify the firms' corporate governance, which usually requires shareholder approval and a lengthy period of execution. Second, no theoretical model suggests that a leverage decision leads to changes in corporate governance. Using two-step system GMM, we report the results in Columns 7-8 of Table 10 on the CGQleverage relation (H2) and confirm similar results as reported earlier in Table 3. That is, the statistically significant negative coefficients of CG index on the CGQ-leverage relation suggest that CGQ significantly reduces leverage.

To further check endogeneity on the stock liquidity-CGQ-leverage relation (H1 and H2), we estimate a regression using changes (first difference) in both the dependent (i.e., leverage) and independent variables (i.e., QS, Amihud, LM and CG index) instead of levels. The regression using first differencing offers at least three advantages. First, the results are generally less likely to show a spurious relation between variables (Chung et al., 2010). Second, this approach helps us to investigate the longer-term effect of independent variables on a dependent variable (Chung et al., 2010). Third, high values of auto correlation (about 0.5 on average) can be reduced by first differencing (Andres et al., 2014). As shown in Table 11, the results show that the coefficients on the changes in QS, Amihud and LM are positive and statistically significant, suggesting that stock liquidity significantly reduces leverage. Similarly, CG index is negative and statistically significant in firms with market leverage and insignificant in firms with book leverage, as reported in Table 4.

[INSERT TABLE 11 here] 


\section{Conclusion}

In this paper, we empirically analyse the relations between 1) stock liquidity and leverage; 2) corporate governance and leverage; and 3) stock liquidity, corporate governance and leverage. In particular, we primarily investigate how both stock liquidity in the order-driven market and CGQ in the insider system of corporate governance influence leverage in Australia.

Using a sample of 1,207 listed firms over the period 2001 to 2013, we find, consistent with our expectation, that stock liquidity affects leverage negatively, suggesting that firms with more stock liquidity exhibit a lower level of debt in their capital structure. We also find that a significantly negative relationship exists between CGQ and leverage, indicating that firms with high CGQ significantly reduce leverage. In a closer analysis, we observe an interactive relationship among stock liquidity, CGQ and leverage: the significantly negative CGQleverage relation exists for firms with high stock liquidity only and not for firms with low stock liquidity. Our study, the first to examine this interactive relationship, provides empirical evidence that the effect of a high CGQ on lowering leverage prevails in highly liquid firms in the Australian context. The findings, which are more economically significant when market leverage is used as the proxy for leverage, are also robust to a range of alternative proxies and to additional tests, implying that stock liquidity and CGQ are important determinants of leverage, that the CGQ-leverage relation is dependent on firms’ stock liquidity.

We contribute to the literature in a number of ways. First, while prior studies examine the relation between stock liquidity-leverage and CGQ-leverage separately, we provide new empirical evidence that the effect of a high CGQ on lowering leverage prevails in highly liquid firms both in Australian and international contexts. This implies that firms with low stock liquidity should attempt to have high governance provisions in order to reduce leverage. To enjoy a lower cost of capital and so lower leverage, small and medium firms would need to improve not only CGQ but also stock liquidity. Second, our study presents robust evidence 
that stock liquidity negatively influences leverage in the order-driven Australian market by incorporating both high and low frequency data, a large sample and an endogeneity bias. Finally, we enrich the literature of corporate governance and leverage by offering the first index-based evidence on the CGQ-leverage relation in the Australian context.

\section{Acknowledgements}

We thank Barry Williams (the guest editor) and two anonymous reviewers for their insightful comments and suggestions to improve the quality of our paper. In the early stage of developing this research idea, our thinking was greatly assisted by completing the "pitching template” created by Faff (2015, 2016). We thank Robert Faff, Zoltan Matolscy, Karen Benson, Gary Monroe, Dave Michayluk, Eliza Wu, Haralc Scheule, and the participants for their helpful comments at the SIRCA's pitching research symposium, University of Technology Sydney, Sydney, 2016. We are also thankful to United Overseas Resources Ltd (Hong Kong) for the financial support, Griffith University Postgraduate Students Association (GUPSA) for the write-up assistance and the SIRCA for the symposium travel grant.

\section{Appendix A. Supplementary data}

This appendix contains information and tabulated results of robustness and additional tests on the relationship among stock liquidity, corporate governance and leverage.

Table A.1 FE estimates of stock liquidity on leverage (H1; alternative proxies)

Table A.2 FE estimates of corporate governance on leverage (H2; alternative proxies)

Table A.3 Size effect of CGQ on leverage (H2)

Table A.4 GFC effect of CGQ on leverage (H2)

Table A.5 FE estimates of stock liquidity and corporate governance on leverage (H1 \& H2; alternative proxies)

Table A.6 FE estimates of CGQ on leverage in high and low liquidity firms (H3; alternative proxies)

\section{References}

Agha, M., 2013. Leverage, executive incentives and corporate governance. Accounting \& Finance. 53, 1-30.

Aitken, M., Comerton Forde, C., Frino, A., 2005. Closing call auctions and liquidity. Accounting \& Finance. 45, 501-518.

Aitken, M., Frino, A., 1996. The determinants of market bid ask spreads on the australian stock exchange: cross-sectional analysis. Accounting \& Finance. 36, 51-63. 
Ali, S., Liu, B., Su, J. J., 2015. Corporate governance and stock liquidity: panel evidence from 2001 to 2013. Paper presented at the 23rd Conference on the Theories and Practices of Securities and Financial Markets, Taiwan.

Ali, S., Liu, B., Su, J. J., 2016. What determines stock liquidity in Australia? Applied Economics. 48, 3329-3344.

Amihud, Y., Mendelson, H., 1986. Asset pricing and the bid-ask spread. Journal of Financial Economics. 17, 223-249.

Amihud, Y., Mendelson, H., 1989. The effects of beta, bid-ask spread, residual risk, and size on stock returns. The Journal of Finance. 44, 479-486.

Andres, C., Cumming, D., Karabiber, T., Schweizer, D., 2014. Do markets anticipate capital structure decisions? - feedback effects in equity liquidity. Journal of Corporate Finance. 27, 133-156.

Beedles, W. L., Dodd, P., Officer, R. R., 1988. Regularities in Australian share returns. Australian Journal of Management. 13, 1-29.

Beekes, W., Brown, P., Zhang, Q., 2015. Corporate governance and the informativeness of disclosures in Australia: a re-examination. Accounting \& Finance. 55, 931-963.

Bhatia, A., Ali, M. J., Balachandran, B., Jurdi, D., 2015. Audit fees and capital structure decision. Paper presented at the 6th Financial Markets and Corporate Governance Conference, Fremantle, Western Australia.

Brailsford, T. J., Oliver, B. R., Pua, S. L., 2002. On the relation between ownership structure and capital structure. Accounting \& Finance. 42, 1-26.

Brennan, M. J., Chordia, T., Subrahmanyam, A., 1998. Alternative factor specifications, security characteristics, and the cross-section of expected stock returns. Journal of Financial Economics. 49, 345-373.

Brennan, M. J., Subrahmanyam, A., 1996. Market microstructure and asset pricing: on the compensation for illiquidity in stock returns. Journal of Financial economics. 41, 441464.

Brown, D. P., Zhang, Z. M., 1997. Market orders and market efficiency. The Journal of Finance. 52, 277-308.

Carstensen, K., Toubal, F., 2004. Foreign direct investment in Central and Eastern European countries: a dynamic panel analysis. Journal of Comparative Economics. 32, 3-22.

Cassar, G., Holmes, S., 2003. Capital structure and financing of SMEs: Australian evidence. Accounting \& Finance. 43, 123-147.

Chai, D., Faff, R., Gharghori, P., 2010. New evidence on the relation between stock liquidity and measures of trading activity. International Review of Financial Analysis. 19, 181192.

Chan, H. W., Faff, R. W., 2003. An investigation into the role of liquidity in asset pricing: Australian evidence. Pacific-Basin Finance Journal. 11, 555-572.

Chang, Chou, R. K., Huang, T. H., 2014. Corporate governance and the dynamics of capital structure: new evidence. Journal of Banking \& Finance. 48, 374-385.

Christensen, J., Kent, P., Routledge, J., Stewart, J., 2015. Do corporate governance recommendations improve the performance and accountability of small listed companies? Accounting \& Finance. 55, 133-164.

Chung, K. H., Elder, J., Kim, J. C., 2010. Corporate governance and liquidity. Journal of Financial and Quantitative Analysis. 45, 265-291.

Clayman, M. R., Fridson, M. S., Troughton, G. H., 2012. Corporate finance: a practical approach, second ed., Hoboken, New Jersey, John Wiley \& Sons.

Dang, V. A., 2013. An empirical analysis of zero-leverage firms: new evidence from the UK. International Review of Financial Analysis. 30, 189-202.

Deesomsak, R., Paudyal, K., Pescetto, G., 2004. The determinants of capital structure: evidence from the Asia Pacific region. Journal of Multinational Financial Management. 14, 387-405.

Dignam, A. J., Galanis, M., 2004. Australia inside/out: the corporate governance system of 
the Australian listed market. Melbourne Univeristy Law Review. 28.

Drobetz, W., Schillhofer, A., Zimmermann, H., 2004. Corporate governance and expected stock returns: evidence from Germany. European Financial Management. 10, 267-293.

Fabre, J., Frino, A., 2004. Commonality in liquidity: evidence from the Australian stock exchange. Accounting \& Finance. 44, 357-368.

Faff, R. W., 2015. A simple template for pitching research. Accounting \& Finance. 55, 311336.

Faff, R. W., 2016. Pitching Research. Working paper at University of Queensland. Retrieved from https://ssrn.com/abstract=2462059.

Fan, J., Titman, S., Twite, G., 2012. An international comparison of capital structure and debt maturity choices. Journal of Financial and Quantitative Analysis. 47, 23-56.

Fang, V. W., Noe, T. H., Tice, S., 2009. Stock market liquidity and firm value. Journal of Financial Economics. 94, 150-169.

Faulkender, M., Petersen, M. A., 2006. Does the source of capital affect capital structure? Review of Financial Studies. 19, 45-79.

Frank, M. Z., Goyal, V. K., 2009. Capital structure decisions: which factors are reliably important? Financial Management. 38, 1-37.

Frieder, L., Martell, R., 2006. On capital structure and the liquidity of a firm's stock. Working paper at Purdue University.

Gaud, P., Jani, E., Hoesli, M., Bender, A., 2005. The capital structure of Swiss companies: an empirical analysis using dynamic panel data. European Financial Management. 11, 5169.

Gompers, P. A., Ishii, J. L., Metrick, A., 2003. Corporate governance and equity prices. Quarterly Journal of Economics. 118, 107-155.

Graham, J. R., Harvey, C. R., 2001. The theory and practice of corporate finance: evidence from the field. Journal of Financial Economics. 60, 187-243.

Haque, F., Arun, T. G., Kirkpatrick, C., 2011. Corporate governance and capital structure in developing countries: a case study of Bangladesh. Applied Economics. 43, 673-681.

Jensen, M. C., 1986. Agency cost of free cash flow, corporate finance, and takeovers. American Economic Review. 76.

Jensen, M. C., Meckling, W. H., 1976. Theory of the firm: managerial behavior, agency costs and ownership structure. Journal of Financial Economics. 3, 305-360.

Jiraporn, P., Gleason, K. C., 2007. Capital structure, shareholder rights, and corporate governance. Journal of Financial Research. 30, 21-33.

Jiraporn, P., Kim, J. C., Kim, Y. S., Kitsabunnarat, P., 2012. Capital structure and corporate governance quality: evidence from the Institutional Shareholder Services (ISS). International Review of Economics and Finance. 22, 208-221.

John, K., Litov, L. P., 2010. Corporate governance and financing policy: new evidence. Working paper at Washington University.

Johnson, S. A., 2003. Debt maturity and the effects of growth opportunities and liquidity risk on leverage. Review of Financial Studies. 16, 209-236.

Khan, A., Mather, P., Balachandran, B., 2014. Managerial share ownership and operating performance: Do independent and executive directors have different incentives? Australian Journal of Management. 39, 47-71.

Klock, M. S., Mansi, S. A., Maxwell, W. F., 2005. Does corporate governance matter to bondholders? Journal of Financial and Quantitative Analysis. 40, 693-719.

Kochhar, R., 1996. Explaining firm capital structure: the role of agency theory vs. transaction cost economics. Strategic Management Journal. 17, 713-728.

Liao, L. K. C., Mukherjee, T., Wang, W., 2015. Corporate governance and capital structure dynamics: an empirical study. Journal of Financial Research. 38, 169-192.

Limkriangkrai, M., Durand, R. B., Watson, I., 2008. Is liquidity the missing link? Accounting \& Finance. 48, 829-845.

Lipson, M. L., Mortal, S., 2009. Liquidity and capital structure. Journal of Financial Markets. 
12, 611-644.

Liu, W., 2006. A liquidity-augmented capital asset pricing model. Journal of Financial Economics. 82, 631-671.

McColgan, P., 2001. Agency theory and corporate governance: a review of the literature from a UK perspective. Working paper at University of Strathclyde.

Mendez, C. F., Pathan, S., García, R. A., 2015. Monitoring capabilities of busy and overlap directors: evidence from Australia. Pacific-Basin Finance Journal. 35, 444-469.

Millicent, C., Gino, D. A., Iain, W., Marvin, W., 2008. Does disclosure quality via investor relations affect information asymmetry? Australian Journal of Management. 33, 375390.

Modigliani, F., Miller, M. H., 1958. The cost of capital, corporation finance and the theory of investment. The American Economic Review. 48, 261-297.

Mohamed, A. E., Seelanatha, S. L., 2014. The Global Financial Crisis (GFC), equity market liquidity and capital structure: evidence from Australia. Journal of Applied Research in Accounting and Finance (JARAF). 9, 13-26.

Myers, S. C., 1977. Determinants of corporate borrowing. Journal of Financial Economics. 5, 147-175.

Myers, S. C., Majluf, N. S., 1984. Corporate financing and investment decisions when firms have information that investors do not have. Journal of Financial Economics. 13, 187221.

Nguyen, T., Duong, H. N., Singh, H., 2016. Stock market liquidity and firm value: an empirical examination of the Australian market. International Review of Finance. doi:10.1111/irfi.12082.

Pathan, S., 2009. Strong boards, CEO power and bank risk-taking. Journal of Banking \& Finance. 33, 1340-1350.

Pham, P. K., Suchard, J. A., Zein, J., 2011. Corporate governance and alternative performance measures: evidence from Australian firms. Australian Journal of Management. 36, 371-386.

Ross, S. A., 1977. The determination of financial structure: the incentive-signalling approach. The Bell Journal of Economics. 8, 23-40.

Shleifer, A., Vishny, R. W., 1997. A survey of corporate governance. The Journal of Finance. 52, 737-783.

Smith, D. J., Chen, J., Anderson, H. D., 2015. The influence of firm financial position and industry characteristics on capital structure adjustment. Accounting \& Finance. 55, 1135-1169.

Stoll, H. R., Whaley, R. E., 1983. Transaction costs and the small firm effect. Journal of Financial Economics. 12, 57-79.

Strebulaev, I. A., Yang, B., 2013. The mystery of zero-leverage firms. Journal of Financial Economics. 109, 1-23.

Udomsirikul, P., Jumreornvong, S., Jiraporn, P., 2011. Liquidity and capital structure: The case of Thailand. Journal of Multinational Financial Management. 21, 106-117.

Welker, M., 1995. Disclosure policy, information asymmetry, and liquidity in equity markets. Contemporary Accounting Research. 11, 801-827.

Wintoki, M. B., Linck, J. S., Netter, J. M., 2012. Endogeneity and the dynamics of internal corporate governance. Journal of Financial Economics. 105, 581-606.

Yarram, S. R., 2013a. Influence of corporate board structure and functioning on financial leverage of Australians firms. Global Review of Business and Economic Research. 9, $1-16$.

Yarram, S. R., 2013b. Ownership and Financial Leverage: Australian evidence. The Asia Pacific Journal of Economics \& Business. 17, 13-23. 
Table 1

Variables, notations, and definitions

\begin{tabular}{lll}
\hline Variable & Notation & Definition \\
\hline $\begin{array}{l}\text { Proxies for leverage } \\
\text { Book leverage }\end{array}$ & BL & $\begin{array}{l}\text { (Short-term debt }+ \text { long-term debt)/ book } \\
\text { value of assets } \\
\text { (Short-term debt + long-term debt)/ (short- } \\
\text { term debt + long-term debt + market value of } \\
\text { equity) }\end{array}$
\end{tabular}

Proxies for corporate governance

Corporate governance index CGQ

\section{Proxies for stock liquidity}

Time-weighted quoted spread

Amihud illiquidity estimate Amihud

Turnover-adjusted zero daily LM volumes

\section{Proxies for control variables}

Firm size

Tangibility

Growth opportunities

Firm age

Profitability

Firm risk

Non-debt tax shields

Asset liquidity

Ownership concentration

Share price

Year effect
QS

Size Natural log of total assets

Tang

MTB

Age

ROA

Risk

NDTS

Assetliq

Top-20

STPrice

YR financial year financial year assets listing shareholders

Natural log of stock price
Constructed CG index based on 17 objective criteria of the Horwath report

Daily ratio of time-weighted bid-ask spread divided by time-weighted mid-point spread averaged over the number of trading days in a

Natural log of daily ratio of absolute stock return to trading volume in Australian dollars averaged over the number of trading days in a

Turnover-adjusted zero daily volumes

Net property, plant, and equipment to total

Market value to book value

Natural log of number of years since the firm's

Earnings before interest and tax to total assets Standard deviation of the return

Annual depreciation expense to total assets

Current assets to current liabilities

Percentage of shares held by the top-20

Thirteen individual dummy variables which equals either " 1 " or " 0 " for each year from 2001 to 2013, with 2001 being the excluded year 
Table 2

Descriptive statistics

\begin{tabular}{lccccc}
\hline Variable & Mean & STD & P25 & P50 & P75 \\
\hline Leverage & & & & & \\
BL & 0.36 & 0.24 & 0.13 & 0.35 & 0.54 \\
ML & 0.27 & 0.23 & 0.06 & 0.22 & 0.43
\end{tabular}

Stock liquidity

QS

Amihud

$\begin{array}{lllll}0.05 & 0.06 & 0.01 & 0.03 & 0.07 \\ -14.03 & 2.83 & -15.83 & -13.50 & -11.92 \\ 4.08 & 5.64 & 0.20 & 0.98 & 6.18\end{array}$

\section{Corporate governance}

CG index

$\begin{array}{lllll}8.46 & 4.54 & 5.00 & 9.00 & 12.00\end{array}$

Firm-specific determinants

\begin{tabular}{llllll} 
MTB & 2.48 & 2.29 & 0.90 & 1.68 & 3.14 \\
ROA & -0.09 & 0.27 & -0.15 & 0.01 & 0.08 \\
Assetliq & 0.20 & 0.22 & 0.04 & 0.11 & 0.30 \\
Size & 18.07 & 2.18 & 16.54 & 17.89 & 19.43 \\
Tang & 0.22 & 0.23 & 0.03 & 0.13 & 0.38 \\
Top-20 & 63.59 & 20.49 & 50.45 & 65.77 & 79.20 \\
NDTS & -0.02 & 0.02 & -0.03 & -0.02 & 0.00 \\
STPrice & -0.77 & 1.89 & -2.12 & -0.78 & 0.67 \\
Risk & 0.04 & 0.02 & 0.02 & 0.04 & 0.05 \\
Age (in years) & 13.73 & 10.46 & 5.52 & 11.17 & 19.41 \\
Age (ln) & 2.27 & 0.92 & 1.71 & 2.41 & 2.97 \\
\hline This table presents mean, standard deviation (SD), 25\% percentile (P25), 50\% percentile (P50) and 75\% \\
percentile (P75) for main proxies of leverage, stock liquidity and corporate governance along with control \\
variables. The definition of variables is provided in Table 1.
\end{tabular}


Table 3

FE estimates of stock liquidity on leverage (H1) and corporate governance on leverage (H2)

\begin{tabular}{|c|c|c|c|c|c|c|c|c|}
\hline & \multicolumn{2}{|l|}{ QS } & \multicolumn{2}{|l|}{ Amihud } & \multicolumn{2}{|l|}{ LM } & \multicolumn{2}{|l|}{ CGQ } \\
\hline & $\begin{array}{l}\text { BL } \\
\text { (1) }\end{array}$ & $\begin{array}{l}\text { ML } \\
\text { (2) }\end{array}$ & $\begin{array}{l}\text { BL } \\
\text { (3) }\end{array}$ & $\begin{array}{l}\text { ML } \\
\text { (4) }\end{array}$ & $\begin{array}{l}\text { BL } \\
(5)\end{array}$ & $\begin{array}{l}\text { ML } \\
\text { (6) }\end{array}$ & $\begin{array}{l}\text { BL } \\
\text { (7) }\end{array}$ & $\begin{array}{l}\text { ML } \\
\text { (8) }\end{array}$ \\
\hline QS & $\begin{array}{l}0.655^{* * * *} \\
(7.31)\end{array}$ & $\begin{array}{l}0.676^{* * * *} \\
(9.04)\end{array}$ & & & & & & \\
\hline Amihud & & & $\begin{array}{l}0.006^{* * *} \\
(3.61)\end{array}$ & $\begin{array}{l}0.011^{* * *} \\
(7.08)\end{array}$ & & & & \\
\hline LM & & & & & $\begin{array}{l}0.007 * * * \\
(7.58)\end{array}$ & $\begin{array}{l}0.009 * * * \\
(10.67)\end{array}$ & & \\
\hline CG index & & & & & & & $\begin{array}{l}-0.0018 * \\
(-1.71)\end{array}$ & $\begin{array}{l}-0.034^{* * *} \\
(-3.97)\end{array}$ \\
\hline MTB & $\begin{array}{l}0.023 * * * \\
(11.02)\end{array}$ & $\begin{array}{l}-0.005^{* * *} \\
(-3.70)\end{array}$ & $\begin{array}{l}0.023^{* * * *} \\
(10.56)\end{array}$ & $\begin{array}{l}-0.005^{* * *} \\
(-3.58)\end{array}$ & $\begin{array}{l}0.023^{* * *} \\
(11.10)\end{array}$ & $\begin{array}{l}-0.004^{* * *} \\
(-3.16)\end{array}$ & $\begin{array}{l}0.022 * * * \\
(23.65)\end{array}$ & $\begin{array}{l}-0.006^{* * *} \\
(-7.54)\end{array}$ \\
\hline ROA & $\begin{array}{l}-0.105^{* * *} \\
(-7.70)\end{array}$ & $\begin{array}{l}-0.066 * * * \\
(-6.12)\end{array}$ & $\begin{array}{l}-0.101^{* * *} \\
(-7.17)\end{array}$ & $\begin{array}{l}-0.065 * * * \\
(-5.69)\end{array}$ & $\begin{array}{l}-0.107 * * * \\
(-7.80)\end{array}$ & $\begin{array}{l}-0.069 * * * \\
(-6.44)\end{array}$ & $\begin{array}{l}-0.097 * * * \\
(-11.46)\end{array}$ & $\begin{array}{l}-0.059 * * * \\
(-8.37)\end{array}$ \\
\hline Assetliq & $\begin{array}{l}-0.165^{* * *} \\
(-9.63)\end{array}$ & $\begin{array}{l}-0.114^{* * *} \\
(-8.68)\end{array}$ & $\begin{array}{l}-0.169 * * * \\
(-9.60)\end{array}$ & $\begin{array}{l}-0.116^{* * *} \\
(-8.42)\end{array}$ & $\begin{array}{l}-0.164 * * * \\
(-9.57)\end{array}$ & $\begin{array}{l}-0.112^{* * *} \\
(-8.54)\end{array}$ & $\begin{array}{l}-0.171^{* * *} \\
(-17.33)\end{array}$ & $\begin{array}{l}-0.119 * * * \\
(-14.52)\end{array}$ \\
\hline Size & $\begin{array}{l}0.035^{* * * *} \\
(5.41)\end{array}$ & $\begin{array}{l}0.073^{* * *} \\
(16.25)\end{array}$ & $\begin{array}{l}0.027 * * * \\
(4.01)\end{array}$ & $\begin{array}{l}0.069 * * * \\
(13.92)\end{array}$ & $\begin{array}{l}0.035^{* * * *} \\
(5.57)\end{array}$ & $\begin{array}{l}0.076^{* * * *} \\
(16.77)\end{array}$ & $\begin{array}{l}0.023^{* * *} \\
(9.66)\end{array}$ & $\begin{array}{l}0.062 * * * \\
(31.43)\end{array}$ \\
\hline Tang & $\begin{array}{l}0.176^{* * * *} \\
(8.10)\end{array}$ & $\begin{array}{l}0.079 * * * \\
(4.84)\end{array}$ & $\begin{array}{l}0.175^{* * * *} \\
(8.06)\end{array}$ & $\begin{array}{l}0.080 * * * \\
(4.92)\end{array}$ & $\begin{array}{l}0.173^{* * *} \\
(7.96)\end{array}$ & $\begin{array}{l}0.076^{* * * *} \\
(4.64)\end{array}$ & $\begin{array}{l}0.174 * * * \\
(14.57)\end{array}$ & $\begin{array}{l}0.079 * * * \\
(7.93)\end{array}$ \\
\hline Top-20 & $\begin{array}{l}-0.000 \\
(-0.93)\end{array}$ & $\begin{array}{l}-0.000 \\
(-1.45)\end{array}$ & $\begin{array}{l}0.000 \\
(0.45)\end{array}$ & $\begin{array}{l}0.000 \\
(0.01)\end{array}$ & $\begin{array}{l}-0.000 \\
(-1.21)\end{array}$ & $\begin{array}{l}-0.000 * * \\
(-2.25)\end{array}$ & $\begin{array}{l}0.000 \\
(1.50)\end{array}$ & $\begin{array}{l}0.000 \\
(1.64)\end{array}$ \\
\hline NDTS & $\begin{array}{l}-1.417^{* * * *} \\
(-8.84)\end{array}$ & $\begin{array}{l}-1.026 * * * \\
(-8.22)\end{array}$ & $\begin{array}{l}-1.432 * * * \\
(-8.93)\end{array}$ & $\begin{array}{l}-1.062^{* * *} \\
(-8.48)\end{array}$ & $\begin{array}{l}-1.438 * * * \\
(-8.95)\end{array}$ & $\begin{array}{l}-1.053 * * * \\
(-8.42)\end{array}$ & $\begin{array}{l}-1.417^{* * *} \\
(-14.56)\end{array}$ & $\begin{array}{l}-1.039 * * * \\
(-12.83)\end{array}$ \\
\hline STPrice & $\begin{array}{l}-0.033^{* * *} \\
(-7.54)\end{array}$ & $\begin{array}{l}-0.072 * * * \\
(-18.51)\end{array}$ & $\begin{array}{l}-0.037 * * * \\
(-8.41)\end{array}$ & $\begin{array}{l}-0.074 * * * \\
(-19.27)\end{array}$ & $\begin{array}{l}-0.035^{* * *} \\
(-7.93)\end{array}$ & $\begin{array}{l}-0.073 * * * \\
(-19.20)\end{array}$ & $\begin{array}{l}-0.039 * * * \\
(-17.94)\end{array}$ & $\begin{array}{l}-0.078 * * * \\
(-42.89)\end{array}$ \\
\hline Risk & $\begin{array}{l}-0.486^{* * *} \\
(-2.73)\end{array}$ & $\begin{array}{l}-0.024 \\
(-0.16)\end{array}$ & $\begin{array}{l}-0.834^{* * *} \\
(-4.48)\end{array}$ & $\begin{array}{l}-0.521 * * * \\
(-3.22)\end{array}$ & $\begin{array}{l}-0.061 \\
(-0.34)\end{array}$ & $\begin{array}{l}0.503^{* * * *} \\
(3.30)\end{array}$ & $\begin{array}{l}-0.638^{* * *} \\
(-4.79)\end{array}$ & $\begin{array}{l}-0.185^{*} \\
(-1.67)\end{array}$ \\
\hline Age & $\begin{array}{l}0.028 * * * \\
(3.29)\end{array}$ & $\begin{array}{l}0.014^{*} \\
(1.86)\end{array}$ & $\begin{array}{l}0.029 * * * \\
(3.43)\end{array}$ & $\begin{array}{l}0.015 * * \\
(2.00)\end{array}$ & $\begin{array}{l}0.026^{* * * *} \\
(3.10)\end{array}$ & $\begin{array}{l}0.011 \\
(1.58)\end{array}$ & $\begin{array}{l}0.029 * * * \\
(5.60)\end{array}$ & $\begin{array}{l}0.015^{* * *} \\
(3.48)\end{array}$ \\
\hline Constant & $\begin{array}{l}-0.448 * * * \\
(-3.90)\end{array}$ & $\begin{array}{l}-1.130 * * * \\
(-13.99)\end{array}$ & $\begin{array}{l}-0.198 * \\
(-1.80)\end{array}$ & $\begin{array}{l}-0.867 * * * \\
(-10.35)\end{array}$ & $\begin{array}{l}-0.469 * * * \\
(-4.11)\end{array}$ & $\begin{array}{l}-1.193^{* * *} \\
(-14.71)\end{array}$ & $\begin{array}{l}-0.218^{* * *} \\
(-4.99)\end{array}$ & $\begin{array}{l}-0.904 * * * \\
(-24.89)\end{array}$ \\
\hline Year effect & Yes & Yes & Yes & Yes & Yes & Yes & Yes & Yes \\
\hline Observations & 9855 & 9855 & 9855 & 9855 & 9855 & 9855 & 9855 & 9855 \\
\hline Adj. $\mathrm{R}^{2}$ & 0.233 & 0.422 & 0.219 & 0.411 & 0.233 & 0.428 & 0.109 & 0.321 \\
\hline
\end{tabular}

This table reports the results of FE estimation on the impact of stock liquidity on leverage (Eq.6, Columns 1-6) and on the impact of corporate governance on leverage (Eq.7, Columns 7-8). The independent variables include stock liquidity (QS, Amihud and LM) and CGQ measured by CG index following the Horwath CG report. The dependent variable is leverage, which is defined as the ratio of total debt to book value of assets (BL) and market value of assets (ML). The definition of variables is provided in Table 1. $t$ statistics are given in parentheses. ${ }^{*}, * *, * * *$ represent significant at the $10 \%, 5 \%$, and $1 \%$ levels, respectively. 
Table 4

FE estimates of stock liquidity and corporate governance on leverage (H1 \& H2)

\begin{tabular}{|c|c|c|c|c|c|c|}
\hline & \multicolumn{2}{|l|}{ QS } & \multicolumn{2}{|l|}{ Amihud } & \multicolumn{2}{|l|}{ LM } \\
\hline & $\begin{array}{l}\text { BL } \\
\text { (1) }\end{array}$ & $\begin{array}{l}\text { ML } \\
(2)\end{array}$ & $\begin{array}{l}\text { BL } \\
\text { (3) }\end{array}$ & $\begin{array}{l}\text { ML } \\
\text { (4) }\end{array}$ & $\begin{array}{l}\text { BL } \\
(5)\end{array}$ & $\begin{array}{l}\text { ML } \\
\text { (6) }\end{array}$ \\
\hline QS & $\begin{array}{l}0.652 * * * \\
(13.59)\end{array}$ & $\begin{array}{l}0.669 * * * \\
(16.87)\end{array}$ & & & & \\
\hline Amihud & & & $\begin{array}{l}0.006^{* * * *} \\
(5.23)\end{array}$ & $\begin{array}{l}0.010^{* * * *} \\
(10.80)\end{array}$ & & \\
\hline LM & & & & & $\begin{array}{l}0.007 * * * \\
(13.41)\end{array}$ & $\begin{array}{l}0.009 * * * \\
(19.27)\end{array}$ \\
\hline CG index & $\begin{array}{l}-0.001 \\
(-1.02)\end{array}$ & $\begin{array}{l}-0.002^{* * *} \\
(-3.17)\end{array}$ & $\begin{array}{l}-0.001 \\
(-1.28)\end{array}$ & $\begin{array}{l}-0.002^{* * *} \\
(-3.12)\end{array}$ & $\begin{array}{l}-0.001 \\
(-0.93)\end{array}$ & $\begin{array}{l}-0.001 * * * \\
(-2.91)\end{array}$ \\
\hline МTB & $\begin{array}{l}0.023 * * * \\
(24.87)\end{array}$ & $\begin{array}{l}-0.005^{* * *} \\
(-6.35)\end{array}$ & $\begin{array}{l}0.023 * * * \\
(24.12)\end{array}$ & $\begin{array}{l}-0.005 * * * \\
(-6.36)\end{array}$ & $\begin{array}{l}0.023 * * * \\
(25.25)\end{array}$ & $\begin{array}{l}-0.004^{* * *} \\
(-5.50)\end{array}$ \\
\hline ROA & $\begin{array}{l}-0.106 * * * \\
(-12.61)\end{array}$ & $\begin{array}{l}-0.068^{* * *} \\
(-9.80)\end{array}$ & $\begin{array}{l}-0.101^{* * *} \\
(-11.94)\end{array}$ & $\begin{array}{l}-0.066 * * * \\
(-9.44)\end{array}$ & $\begin{array}{l}-0.107 * * * \\
(-12.73)\end{array}$ & $\begin{array}{l}-0.071 * * * \\
(-10.23)\end{array}$ \\
\hline Assetliq & $\begin{array}{l}-0.165^{* * *} \\
(-16.86)\end{array}$ & $\begin{array}{l}-0.113^{* * *} \\
(-13.96)\end{array}$ & $\begin{array}{l}-0.168 * * * \\
(-17.04)\end{array}$ & $\begin{array}{l}-0.114 * * * \\
(-13.99)\end{array}$ & $\begin{array}{l}-0.164 * * * \\
(-16.72)\end{array}$ & $\begin{array}{l}-0.110 * * * \\
(-13.72)\end{array}$ \\
\hline Size & $\begin{array}{l}0.035 * * * \\
(13.95)\end{array}$ & $\begin{array}{l}0.075^{* * * *} \\
(35.85)\end{array}$ & $\begin{array}{l}0.028 * * * \\
(10.89)\end{array}$ & $\begin{array}{l}0.070 * * * \\
(33.42)\end{array}$ & $\begin{array}{l}0.036 * * * \\
(14.09)\end{array}$ & $\begin{array}{l}0.078 * * * \\
(36.99)\end{array}$ \\
\hline Tang & $\begin{array}{l}0.176^{* * * *} \\
(14.91)\end{array}$ & $\begin{array}{l}0.081^{* * * *} \\
(8.28)\end{array}$ & $\begin{array}{l}0.176^{* * *} \\
(14.75)\end{array}$ & $\begin{array}{l}0.082^{* * * *} \\
(8.30)\end{array}$ & $\begin{array}{l}0.173 * * * \\
(14.64)\end{array}$ & $\begin{array}{l}0.078 * * * \\
(7.98)\end{array}$ \\
\hline Тор-20 & $\begin{array}{l}-0.000 \\
(-1.37)\end{array}$ & $\begin{array}{l}-0.000 * \\
(-1.91)\end{array}$ & $\begin{array}{l}0.000 \\
(0.74)\end{array}$ & $\begin{array}{l}0.000 \\
(0.10)\end{array}$ & $\begin{array}{l}-0.000 * \\
(-1.79)\end{array}$ & $\begin{array}{l}-0.000 * * * \\
(-3.05)\end{array}$ \\
\hline NDTS & $\begin{array}{l}-1.426 * * * \\
(-14.81)\end{array}$ & $\begin{array}{l}-1.048^{* * *} \\
(-13.16)\end{array}$ & $\begin{array}{l}-1.443 * * * \\
(-14.83)\end{array}$ & $\begin{array}{l}-1.083 * * * \\
(-13.46)\end{array}$ & $\begin{array}{l}-1.446 * * * \\
(-15.01)\end{array}$ & $\begin{array}{l}-1.073 * * * \\
(-13.54)\end{array}$ \\
\hline STPrice & $\begin{array}{l}-0.033 * * * \\
(-15.09)\end{array}$ & $\begin{array}{l}-0.072 * * * \\
(-39.41)\end{array}$ & $\begin{array}{l}-0.037 * * * \\
(-16.67)\end{array}$ & $\begin{array}{l}-0.074 * * * \\
(-40.41)\end{array}$ & $\begin{array}{l}-0.035 * * * \\
(-16.09)\end{array}$ & $\begin{array}{l}-0.073 * * * \\
(-40.72)\end{array}$ \\
\hline Risk & $\begin{array}{l}-0.488 * * * \\
(-3.69)\end{array}$ & $\begin{array}{l}-0.032 \\
(-0.29)\end{array}$ & $\begin{array}{l}-0.833^{* * *} \\
(-6.03)\end{array}$ & $\begin{array}{l}-0.518 * * * \\
(-4.54)\end{array}$ & $\begin{array}{l}-0.066 \\
(-0.47)\end{array}$ & $\begin{array}{l}0.491 * * * \\
(4.31)\end{array}$ \\
\hline Age & $\begin{array}{l}0.028 * * * \\
(5.43)\end{array}$ & $\begin{array}{l}0.014^{* * *} \\
(3.25)\end{array}$ & $\begin{array}{l}0.029 * * * \\
(5.58)\end{array}$ & $\begin{array}{l}0.015^{* * * *} \\
(3.44)\end{array}$ & $\begin{array}{l}0.026^{* * * *} \\
(5.09)\end{array}$ & $\begin{array}{l}0.012 * * * \\
(2.74)\end{array}$ \\
\hline Constant & $\begin{array}{l}-0.454 * * * \\
(-9.75)\end{array}$ & $\begin{array}{l}-1.147 * * * \\
(-29.76)\end{array}$ & $\begin{array}{l}-0.207 * * * \\
(-4.75)\end{array}$ & $\begin{array}{l}-0.886 * * * \\
(-24.53)\end{array}$ & $\begin{array}{l}-0.475 * * * \\
(-10.04)\end{array}$ & $\begin{array}{l}-1.208 * * * \\
(-31.04)\end{array}$ \\
\hline Year effect & Yes & Yes & Yes & Yes & Yes & Yes \\
\hline Observations & 9855 & 9855 & 9855 & 9855 & 9855 & 9855 \\
\hline Adj. $\mathrm{R}^{2}$ & 0.127 & 0.342 & 0.111 & 0.330 & 0.127 & 0.349 \\
\hline
\end{tabular}

This table reports the results of FE estimation of equation (8) on the impact of stock liquidity and corporate governance on leverage. The independent variables include stock liquidity (QS, Amihud and LM) and CGQ measured by CG index following the Horwath CG report. The dependent variable is leverage, which is defined as the ratio of total debt to book value of assets (BL) and market value of assets (ML). The definition of variables is provided in Table 1. $t$ statistics are given in parentheses. ${ }^{*}, * *, * *$ represent significant at the $10 \%, 5 \%$, and $1 \%$ levels, respectively. 
Table 5

FE estimates on interaction effect of CGQ on leverage in high and low liquidity firms (H3)

\begin{tabular}{|c|c|c|c|c|c|c|}
\hline & QS & & Amihud & & LM & \\
\hline & $\begin{array}{l}\text { BL } \\
(1)\end{array}$ & $\begin{array}{l}\text { ML } \\
(2)\end{array}$ & $\begin{array}{l}\text { BL } \\
\text { (3) }\end{array}$ & $\begin{array}{l}\text { ML } \\
\text { (4) }\end{array}$ & $\begin{array}{l}\text { BL } \\
(5)\end{array}$ & $\begin{array}{l}\text { ML } \\
\text { (6) }\end{array}$ \\
\hline CG index & $\begin{array}{l}-0.000 \\
(-0.74)\end{array}$ & $\begin{array}{l}-0.001 \\
(-1.17)\end{array}$ & $\begin{array}{l}-0.000 \\
(-0.30)\end{array}$ & $\begin{array}{l}-0.001 \\
(-1.17)\end{array}$ & $\begin{array}{l}0.000 \\
(0.43)\end{array}$ & $\begin{array}{l}-0.000 \\
(-0.51)\end{array}$ \\
\hline CG index*QS & $\begin{array}{l}-0.001^{* *} \\
(-2.07)\end{array}$ & $\begin{array}{l}-0.002 * * * \\
(-6.27)\end{array}$ & & & & \\
\hline $\begin{array}{l}\text { CG } \\
\text { index*Amihud }\end{array}$ & & & $\begin{array}{l}-0.002 * * * \\
(-3.52)\end{array}$ & $\begin{array}{l}-0.003 * * * \\
(-6.94)\end{array}$ & & \\
\hline CG index*LM & & & & & $\begin{array}{l}-0.002^{* * *} \\
(-4.73)\end{array}$ & $\begin{array}{l}-0.003^{* * *} \\
(-7.43)\end{array}$ \\
\hline MTB & $\begin{array}{l}0.022 * * * \\
(23.72)\end{array}$ & $\begin{array}{l}-0.006 * * * \\
(-7.31)\end{array}$ & $\begin{array}{l}0.022 * * * \\
(23.81)\end{array}$ & $\begin{array}{l}-0.006 * * * \\
(-7.20)\end{array}$ & $\begin{array}{l}0.022 * * * \\
(23.86)\end{array}$ & $\begin{array}{l}-0.006 * * * \\
(-7.24)\end{array}$ \\
\hline ROA & $\begin{array}{l}-0.098 * * * \\
(-11.56)\end{array}$ & $\begin{array}{l}-0.061^{* * *} \\
(-8.71)\end{array}$ & $\begin{array}{l}-0.098 * * * \\
(-11.62)\end{array}$ & $\begin{array}{l}-0.061 * * * \\
(-8.70)\end{array}$ & $\begin{array}{l}-0.100 * * * \\
(-11.81)\end{array}$ & $\begin{array}{l}-0.063 * * * \\
(-8.95)\end{array}$ \\
\hline Assetliq & $\begin{array}{l}-0.171 * * * \\
(-17.33)\end{array}$ & $\begin{array}{l}-0.119 * * * \\
(-14.56)\end{array}$ & $\begin{array}{l}-0.170 * * * \\
(-17.26)\end{array}$ & $\begin{array}{l}-0.118^{* * *} \\
(-14.40)\end{array}$ & $\begin{array}{l}-0.170 * * * \\
(-17.19)\end{array}$ & $\begin{array}{l}-0.117 * * * \\
(-14.32)\end{array}$ \\
\hline Size & $\begin{array}{l}0.024 * * * \\
(9.88)\end{array}$ & $\begin{array}{l}0.065^{* * *} \\
(32.12)\end{array}$ & $\begin{array}{l}0.024 * * * \\
(10.12)\end{array}$ & $\begin{array}{l}0.065^{* * * *} \\
(32.24)\end{array}$ & $\begin{array}{l}0.026 * * * \\
(10.51)\end{array}$ & $\begin{array}{l}0.066^{* * *} \\
(32.40)\end{array}$ \\
\hline Tang & $\begin{array}{l}0.174 * * * \\
(14.59)\end{array}$ & $\begin{array}{l}0.079 * * * \\
(7.99)\end{array}$ & $\begin{array}{l}0.175^{* * *} \\
(14.67)\end{array}$ & $\begin{array}{l}0.081^{* * * *} \\
(8.12)\end{array}$ & $\begin{array}{l}0.174 * * * \\
(14.61)\end{array}$ & $\begin{array}{l}0.079 * * * \\
(7.99)\end{array}$ \\
\hline Top-20 & $\begin{array}{l}0.000 \\
(1.36)\end{array}$ & $\begin{array}{l}0.000 \\
(1.22)\end{array}$ & $\begin{array}{l}0.000 \\
(1.22)\end{array}$ & $\begin{array}{l}0.000 \\
(1.10)\end{array}$ & $\begin{array}{l}0.000 \\
(0.99)\end{array}$ & $\begin{array}{l}0.000 \\
(0.85)\end{array}$ \\
\hline NDTS & $\begin{array}{l}-1.422 * * * \\
(-14.61)\end{array}$ & $\begin{array}{l}-1.052 * * * \\
(-13.02)\end{array}$ & $\begin{array}{l}-1.424 * * * \\
(-14.64)\end{array}$ & $\begin{array}{l}-1.051 * * * \\
(-13.02)\end{array}$ & $\begin{array}{l}-1.439 * * * \\
(-14.79)\end{array}$ & $\begin{array}{l}-1.068 * * * \\
(-13.22)\end{array}$ \\
\hline STPrice & $\begin{array}{l}-0.038 * * * \\
(-17.36)\end{array}$ & $\begin{array}{l}-0.076 * * * \\
(-41.39)\end{array}$ & $\begin{array}{l}-0.038 * * * \\
(-17.44)\end{array}$ & $\begin{array}{l}-0.076 * * * \\
(-41.96)\end{array}$ & $\begin{array}{l}-0.038 * * * \\
(-17.55)\end{array}$ & $\begin{array}{l}-0.077 * * * \\
(-42.34)\end{array}$ \\
\hline Risk & $\begin{array}{l}-0.668^{* * *} \\
(-4.99)\end{array}$ & $\begin{array}{l}-0.261^{* *} \\
(-2.35)\end{array}$ & $\begin{array}{l}-0.706^{* * *} \\
(-5.25)\end{array}$ & $\begin{array}{l}-0.297 * * * \\
(-2.66)\end{array}$ & $\begin{array}{l}-0.657 * * * \\
(-4.94)\end{array}$ & $\begin{array}{l}-0.211^{*} \\
(-1.91)\end{array}$ \\
\hline Age & $\begin{array}{l}0.029 * * * \\
(5.66)\end{array}$ & $\begin{array}{l}0.016 * * * \\
(3.68)\end{array}$ & $\begin{array}{l}0.029 * * * \\
(5.68)\end{array}$ & $\begin{array}{l}0.016^{* * * *} \\
(3.64)\end{array}$ & $\begin{array}{l}0.029 * * * \\
(5.68)\end{array}$ & $\begin{array}{l}0.016^{* * * *} \\
(3.60)\end{array}$ \\
\hline Constant & $\begin{array}{l}-0.232^{* * *} \\
(-5.25)\end{array}$ & $\begin{array}{l}-0.940 * * * \\
(-25.62)\end{array}$ & $\begin{array}{l}-0.240 * * * \\
(-5.44)\end{array}$ & $\begin{array}{l}-0.940 * * * \\
(-25.69)\end{array}$ & $\begin{array}{l}-0.263^{* * *} \\
(-5.90)\end{array}$ & $\begin{array}{l}-0.963 * * * \\
(-25.98)\end{array}$ \\
\hline Control variables & Yes & Yes & Yes & Yes & Yes & Yes \\
\hline Year effect & Yes & Yes & Yes & Yes & Yes & Yes \\
\hline Observations & 9855 & 9855 & 9855 & 9855 & 9855 & 9855 \\
\hline Adj. $\mathrm{R}^{2}$ & 0.109 & 0.324 & 0.110 & 0.325 & 0.111 & 0.325 \\
\hline
\end{tabular}

This table reports the results of FE estimation of equation (9) on the interaction effect of stock liquidity and CGQ on leverage. The independent variables include CGQ (defined as CG index following the Horwath CG report), interaction term of CG index and QS, interaction term of CG index and Amihud and interaction term of CG index and LM. The dependent variable is leverage, which is defined as the ratio of total debt to book value of assets (BL) and market value of assets (ML). The definition of variables is provided in Table 1. $t$ statistics are given in parentheses. *, **, *** represent significant at the $10 \%, 5 \%$, and $1 \%$ levels, respectively. 
Table 6

FE estimates on interaction effect of CGQ on leverage in high and low liquidity firms using reversed CG index and liquidity quintiles (H3)

\begin{tabular}{|c|c|c|c|c|c|c|}
\hline Panel A & QS & & Amihud & & LM & \\
\hline & $\begin{array}{l}\text { BL } \\
\text { (1) }\end{array}$ & $\begin{array}{l}\text { ML } \\
\text { (2) }\end{array}$ & $\begin{array}{l}\text { BL } \\
\text { (3) }\end{array}$ & $\begin{array}{l}\text { ML } \\
\text { (4) }\end{array}$ & $\begin{array}{l}\text { BL } \\
\text { (5) }\end{array}$ & $\begin{array}{l}\text { ML } \\
\text { (6) }\end{array}$ \\
\hline Reversed CG index * QS & $\begin{array}{l}0.045^{* * *} \\
(12.32)\end{array}$ & $\begin{array}{l}0.044 * * * \\
(14.41)\end{array}$ & & & & \\
\hline Reversed CG index * Amihud & & & $\begin{array}{l}0.001^{* * *} \\
(4.88)\end{array}$ & $\begin{array}{l}0.001^{* * *} \\
(7.87)\end{array}$ & & \\
\hline Reversed CG index * LM & & & & & $\begin{array}{l}0.001^{* * * *} \\
(12.30)\end{array}$ & $\begin{array}{l}0.001 * * * \\
(16.70)\end{array}$ \\
\hline Reversed CG index & $\begin{array}{l}-0.002 * * \\
(-2.36)\end{array}$ & $\begin{array}{l}-0.000 \\
(-0.86)\end{array}$ & $\begin{array}{l}0.008 * * * \\
(5.16)\end{array}$ & $\begin{array}{l}0.012^{* * *} \\
(8.80)\end{array}$ & $\begin{array}{l}-0.001 * \\
(-1.68)\end{array}$ & $\begin{array}{l}-0.000 \\
(-0.65)\end{array}$ \\
\hline Control variables & Yes & Yes & Yes & Yes & Yes & Yes \\
\hline Year effect & Yes & Yes & Yes & Yes & Yes & Yes \\
\hline Observations & 9855 & 9855 & 9855 & 9855 & 9855 & 9855 \\
\hline Adj. $\mathrm{R}^{2}$ & 0.124 & 0.337 & 0.111 & 0.326 & 0.124 & 0.342 \\
\hline Panel B & QS & & Amihud & & LM & \\
\hline & $\begin{array}{l}\text { BL } \\
\text { (1) }\end{array}$ & $\begin{array}{l}\text { ML } \\
\text { (2) }\end{array}$ & $\begin{array}{l}\text { BL } \\
\text { (3) }\end{array}$ & $\begin{array}{l}\text { ML } \\
\text { (4) }\end{array}$ & $\begin{array}{l}\text { BL } \\
\text { (5) }\end{array}$ & $\begin{array}{l}\text { ML } \\
\text { (6) }\end{array}$ \\
\hline $\begin{array}{l}\text { CG index } \\
\text { (at top } 40 \% \text { liquidity) }\end{array}$ & $\begin{array}{l}-0.002^{*} \\
(-1.71)\end{array}$ & $\begin{array}{l}-0.004^{* * *} \\
(-4.41)\end{array}$ & $\begin{array}{l}-0.002 * \\
(-1.72)\end{array}$ & $\begin{array}{l}-0.003 * * * \\
(-4.25)\end{array}$ & $\begin{array}{l}-0.002^{* *} \\
(-2.04)\end{array}$ & $\begin{array}{l}-0.004^{* * *} \\
(-4.34)\end{array}$ \\
\hline $\begin{array}{l}\text { CG index } \\
\text { (at middle 20\% liquidity) }\end{array}$ & $\begin{array}{l}-0.002 * \\
(-1.68)\end{array}$ & $\begin{array}{l}-0.002 * * * \\
(-2.74)\end{array}$ & $\begin{array}{l}-0.001 \\
(-1.07)\end{array}$ & $\begin{array}{l}-0.002 * * \\
(-2.38)\end{array}$ & $\begin{array}{l}-0.002 * \\
(-1.69)\end{array}$ & $\begin{array}{l}-0.003^{* * *} \\
(-3.06)\end{array}$ \\
\hline $\begin{array}{l}\text { CG index } \\
\text { (at bottom } 40 \% \text { liquidity) }\end{array}$ & $\begin{array}{l}0.000 \\
(0.29)\end{array}$ & $\begin{array}{l}0.000 \\
(0.38)\end{array}$ & $\begin{array}{l}-0.000 \\
(-0.12)\end{array}$ & $\begin{array}{l}-0.000 \\
(-0.10)\end{array}$ & $\begin{array}{l}0.001 \\
(0.85)\end{array}$ & $\begin{array}{l}0.001 \\
(0.64)\end{array}$ \\
\hline Control variables & Yes & Yes & Yes & Yes & Yes & Yes \\
\hline Year effect & Yes & Yes & Yes & Yes & Yes & Yes \\
\hline Observations & 9855 & 9855 & 9855 & 9855 & 9855 & 9855 \\
\hline Adj. $\mathrm{R}^{2}$ & 0.218 & 0.408 & 0.218 & 0.407 & 0.220 & 0.409 \\
\hline
\end{tabular}

Panel A of this table reports the results of FE estimation of equation (9) on the interaction effect of stock liquidity and CGQ on leverage using reversed CG index. The independent variables include reversed CG index, interaction term of reversed CG index and QS, interaction term of reversed CG index and Amihud and interaction term of reversed CG index and LM. Panel B reports the results of the above equation on the basis of liquidity quintiles. Quintile at the top $40 \%$ represents high liquidity firms while quintile at bottom $40 \%$ represents low liquidity firms. The dependent variable is leverage, which is defined as the ratio of total debt to book value of assets (BL) and market value of assets (ML). The coefficients of control variables are not reported in the interests of brevity. The definition of variables is provided in Table 1 . $t$ statistics are given in parentheses. ${ }^{*}, * *, * * *$ represent significant at the $10 \%, 5 \%$, and $1 \%$ levels, respectively. 
Table 7

FE estimates of CGQ on leverage in high and low liquidity firms (H3)

\begin{tabular}{|c|c|c|c|c|c|c|c|c|c|c|c|c|}
\hline & \multicolumn{4}{|l|}{$\mathrm{QS}$} & \multicolumn{4}{|l|}{ Amihud } & \multicolumn{4}{|l|}{ LM } \\
\hline & High & Low & High & Low & High & Low & High & Low & High & Low & High & Low \\
\hline & $\begin{array}{l}\text { BL } \\
(1)\end{array}$ & $\begin{array}{l}\text { BL } \\
(2)\end{array}$ & $\begin{array}{l}\text { ML } \\
\text { (3) }\end{array}$ & $\begin{array}{l}\text { ML } \\
(4)\end{array}$ & $\begin{array}{l}\text { BL } \\
(5)\end{array}$ & $\begin{array}{l}\text { BL } \\
(6)\end{array}$ & $\begin{array}{l}\text { ML } \\
(7)\end{array}$ & $\begin{array}{l}\text { ML } \\
(8)\end{array}$ & $\begin{array}{l}\text { BL } \\
(9)\end{array}$ & $\begin{array}{l}\text { BL } \\
(10)\end{array}$ & $\begin{array}{l}\text { ML } \\
(11)\end{array}$ & $\begin{array}{l}\text { ML } \\
(12)\end{array}$ \\
\hline CG index & $\begin{array}{l}-0.002^{* *} \\
(-2.33)\end{array}$ & $\begin{array}{l}-0.001 \\
(-0.60)\end{array}$ & $\begin{array}{l}-0.002 * * * \\
(-3.45)\end{array}$ & $\begin{array}{l}-0.002 \\
(-1.25)\end{array}$ & $\begin{array}{l}-0.003 * * * \\
(-3.77)\end{array}$ & $\begin{array}{l}0.001 \\
(0.60)\end{array}$ & $\begin{array}{l}-0.002^{* * *} \\
(-3.36)\end{array}$ & $\begin{array}{l}-0.002 \\
(-1.23)\end{array}$ & $\begin{array}{l}-0.001 \\
(-1.53)\end{array}$ & $\begin{array}{l}0.001 \\
(0.62)\end{array}$ & $\begin{array}{l}-0.002 * * * \\
(-2.67)\end{array}$ & $\begin{array}{l}-0.001 \\
(-1.09)\end{array}$ \\
\hline МТВ & $\begin{array}{l}0.033^{* * *} \\
(25.18)\end{array}$ & $\begin{array}{l}0.018 * * * \\
(12.61)\end{array}$ & $\begin{array}{l}0.000 \\
(0.30)\end{array}$ & $\begin{array}{l}-0.007 * * * \\
(-3.78)\end{array}$ & $\begin{array}{l}0.030 * * * \\
(22.84)\end{array}$ & $\begin{array}{l}0.019 * * * \\
(13.93)\end{array}$ & $\begin{array}{l}-0.001 \\
(-0.67)\end{array}$ & $\begin{array}{l}-0.006^{* * *} \\
(-3.42)\end{array}$ & $\begin{array}{l}0.030 * * * \\
(23.48)\end{array}$ & $\begin{array}{l}0.017^{* * *} \\
(11.97)\end{array}$ & $\begin{array}{l}0.001 \\
(0.77)\end{array}$ & $\begin{array}{l}-0.008 * * * \\
(-4.19)\end{array}$ \\
\hline ROA & $\begin{array}{l}-0.096 * * * \\
(-6.88)\end{array}$ & $\begin{array}{l}-0.081 \text { *** } \\
(-6.80)\end{array}$ & $\begin{array}{l}-0.110^{* * *} \\
(-9.36)\end{array}$ & $\begin{array}{l}-0.039 * * * \\
(-2.91)\end{array}$ & $\begin{array}{l}-0.083 * * * \\
(-5.95)\end{array}$ & $\begin{array}{l}-0.082^{* * *} \\
(-6.80)\end{array}$ & $\begin{array}{l}-0.081 \text { *** } \\
(-6.76)\end{array}$ & $\begin{array}{l}-0.048 * * * \\
(-3.55)\end{array}$ & $\begin{array}{l}-0.119 * * * \\
(-9.74)\end{array}$ & $\begin{array}{l}-0.091 * * * \\
(-7.36)\end{array}$ & $\begin{array}{l}-0.100 * * * \\
(-9.79)\end{array}$ & $\begin{array}{l}-0.047 * * * \\
(-3.14)\end{array}$ \\
\hline Assetliq & $\begin{array}{l}-0.148 * * * \\
(-10.42)\end{array}$ & $\begin{array}{l}-0.177 * * * \\
(-12.27)\end{array}$ & $\begin{array}{l}-0.080^{* * *} \\
(-6.73)\end{array}$ & $\begin{array}{l}-0.137 * * * \\
(-7.27)\end{array}$ & $\begin{array}{l}-0.162 * * * \\
(-10.84)\end{array}$ & $\begin{array}{l}-0.173 * * * \\
(-12.08)\end{array}$ & $\begin{array}{l}-0.098 * * * \\
(-7.69)\end{array}$ & $\begin{array}{l}-0.127 * * * \\
(-7.00)\end{array}$ & $\begin{array}{l}-0.150 * * * \\
(-10.90)\end{array}$ & $\begin{array}{l}-0.186^{* * *} \\
(-12.74)\end{array}$ & $\begin{array}{l}-0.083 * * * \\
(-7.22)\end{array}$ & $\begin{array}{l}-0.137 * * * \\
(-7.39)\end{array}$ \\
\hline Size & $\begin{array}{l}0.073^{* * *} \\
(19.99)\end{array}$ & $\begin{array}{l}0.001 \\
(0.35)\end{array}$ & $\begin{array}{l}0.093 * * * \\
(30.29)\end{array}$ & $\begin{array}{l}0.052^{* * *} \\
(8.33)\end{array}$ & $\begin{array}{l}0.073 * * * \\
(19.49)\end{array}$ & $\begin{array}{l}0.003 \\
(0.79)\end{array}$ & $\begin{array}{l}0.091^{* * *} \\
(28.38)\end{array}$ & $\begin{array}{l}0.056^{* * *} \\
(8.98)\end{array}$ & $\begin{array}{l}0.066^{* * * *} \\
(18.18)\end{array}$ & $\begin{array}{l}0.004 \\
(1.04)\end{array}$ & $\begin{array}{l}0.094 * * * \\
(30.81)\end{array}$ & $\begin{array}{l}0.058^{* * *} \\
(8.75)\end{array}$ \\
\hline Tang & $\begin{array}{l}0.160^{* * *} \\
(10.60)\end{array}$ & $\begin{array}{l}0.139 * * * \\
(7.15)\end{array}$ & $\begin{array}{l}0.059 * * * \\
(4.65)\end{array}$ & $\begin{array}{l}0.081^{* * * *} \\
(3.26)\end{array}$ & $\begin{array}{l}0.154^{* * *} \\
(10.32)\end{array}$ & $\begin{array}{l}0.137 * * * \\
(6.78)\end{array}$ & $\begin{array}{l}0.050 * * * \\
(3.94)\end{array}$ & $\begin{array}{l}0.082^{* * * *} \\
(3.13)\end{array}$ & $\begin{array}{l}0.175^{* * *} \\
(11.85)\end{array}$ & $\begin{array}{l}0.145^{* * *} \\
(7.05)\end{array}$ & $\begin{array}{l}0.072 * * * \\
(5.79)\end{array}$ & $\begin{array}{l}0.082^{* * * *} \\
(3.02)\end{array}$ \\
\hline Top-20 & $\begin{array}{l}-0.001 * * * \\
(-4.04)\end{array}$ & $\begin{array}{l}0.001 * * * \\
(2.82)\end{array}$ & $\begin{array}{l}-0.000^{* * *} \\
(-4.00)\end{array}$ & $\begin{array}{l}0.000 * * \\
(2.28)\end{array}$ & $\begin{array}{l}-0.001 * * * \\
(-3.67)\end{array}$ & $\begin{array}{l}0.001 * * * \\
(2.88)\end{array}$ & $\begin{array}{l}-0.000^{* * *} \\
(-3.82)\end{array}$ & $\begin{array}{l}0.000^{* *} \\
(2.16)\end{array}$ & $\begin{array}{l}-0.000 * * * \\
(-3.03)\end{array}$ & $\begin{array}{l}0.000 \\
(1.11)\end{array}$ & $\begin{array}{l}-0.000 * * * \\
(-3.00)\end{array}$ & $\begin{array}{l}0.000 \\
(1.19)\end{array}$ \\
\hline NDTS & $\begin{array}{l}-0.779 * * * \\
(-6.33)\end{array}$ & $\begin{array}{l}-1.821 * * * \\
(-11.95)\end{array}$ & $\begin{array}{l}-0.520^{* * *} \\
(-5.02)\end{array}$ & $\begin{array}{l}-1.307^{* * *} \\
(-7.06)\end{array}$ & $\begin{array}{l}-0.780^{* * *} \\
(-6.18)\end{array}$ & $\begin{array}{l}-1.745^{* * *} \\
(-11.32)\end{array}$ & $\begin{array}{l}-0.490 * * * \\
(-4.53)\end{array}$ & $\begin{array}{l}-1.284^{* * *} \\
(-7.00)\end{array}$ & $\begin{array}{l}-1.170^{* * *} \\
(-9.32)\end{array}$ & $\begin{array}{l}-1.741^{* * *} \\
(-11.19)\end{array}$ & $\begin{array}{l}-0.785 * * * \\
(-7.49)\end{array}$ & $\begin{array}{l}-1.317 * * * \\
(-6.57)\end{array}$ \\
\hline STPrice & $\begin{array}{l}-0.060 * * * \\
(-19.39)\end{array}$ & $\begin{array}{l}-0.027 * * * \\
(-8.00)\end{array}$ & $\begin{array}{l}-0.103^{* * *} \\
(-39.58)\end{array}$ & $\begin{array}{l}-0.062 * * * \\
(-12.17)\end{array}$ & $\begin{array}{l}-0.059 * * * \\
(-19.06)\end{array}$ & $\begin{array}{l}-0.029 * * * \\
(-8.66)\end{array}$ & $\begin{array}{l}-0.102^{* * *} \\
(-38.14)\end{array}$ & $\begin{array}{l}-0.065^{* * *} \\
(-12.91)\end{array}$ & $\begin{array}{l}-0.051^{* * *} \\
(-16.80)\end{array}$ & $\begin{array}{l}-0.030^{* * *} \\
(-9.10)\end{array}$ & $\begin{array}{l}-0.091 * * * \\
(-36.12)\end{array}$ & $\begin{array}{l}-0.071 * * * \\
(-12.93)\end{array}$ \\
\hline Risk & $\begin{array}{l}-0.623 * * * \\
(-3.19)\end{array}$ & $\begin{array}{l}-0.651 \text { *** } \\
(-3.30)\end{array}$ & $\begin{array}{l}0.276^{*} \\
(1.68)\end{array}$ & $\begin{array}{l}-0.653^{* * * *} \\
(-2.94)\end{array}$ & $\begin{array}{l}-0.926 * * * \\
(-4.61)\end{array}$ & $\begin{array}{l}-0.768^{* * * *} \\
(-3.84)\end{array}$ & $\begin{array}{l}-0.058 \\
(-0.33)\end{array}$ & $\begin{array}{l}-0.517 * * \\
(-2.34)\end{array}$ & $\begin{array}{l}-0.582 * * * \\
(-2.87)\end{array}$ & $\begin{array}{l}-0.679 * * * \\
(-3.55)\end{array}$ & $\begin{array}{l}0.260 \\
(1.54)\end{array}$ & $\begin{array}{l}-0.485^{* *} \\
(-2.27)\end{array}$ \\
\hline Age & $\begin{array}{l}0.009 \\
(1.41)\end{array}$ & $\begin{array}{l}0.037 * * * \\
(3.98)\end{array}$ & $\begin{array}{l}0.001 \\
(0.15)\end{array}$ & $\begin{array}{l}0.018 \\
(1.46)\end{array}$ & $\begin{array}{l}0.008 \\
(1.28)\end{array}$ & $\begin{array}{l}0.029 * * * \\
(3.27)\end{array}$ & $\begin{array}{l}-0.001 \\
(-0.10)\end{array}$ & $\begin{array}{l}0.016 \\
(1.36)\end{array}$ & $\begin{array}{l}0.009 \\
(1.35)\end{array}$ & $\begin{array}{l}0.040^{* * *} \\
(4.67)\end{array}$ & $\begin{array}{l}0.001 \\
(0.22)\end{array}$ & $\begin{array}{l}0.023^{* *} \\
(1.98)\end{array}$ \\
\hline Constant & $\begin{array}{l}-1.036 * * * \\
(-15.08)\end{array}$ & $\begin{array}{l}0.092 \\
(1.37)\end{array}$ & $\begin{array}{l}-1.423^{* * *} \\
(-24.59)\end{array}$ & $\begin{array}{l}-0.727 * * * \\
(-6.53)\end{array}$ & $\begin{array}{l}-1.023 * * * \\
(-14.66)\end{array}$ & $\begin{array}{l}0.081 \\
(1.20)\end{array}$ & $\begin{array}{l}-1.362 * * * \\
(-22.76)\end{array}$ & $\begin{array}{l}-0.796^{* * *} \\
(-7.19)\end{array}$ & $\begin{array}{l}-0.972 \text { *** } \\
(-14.14)\end{array}$ & $\begin{array}{l}0.088 \\
(1.29)\end{array}$ & $\begin{array}{l}-1.501 * * * \\
(-26.18)\end{array}$ & $\begin{array}{l}-0.802 * * * \\
(-6.86)\end{array}$ \\
\hline
\end{tabular}




\begin{tabular}{|c|c|c|c|c|c|c|c|c|c|c|c|c|}
\hline Year effect & Yes & Yes & Yes & Yes & Yes & Yes & Yes & Yes & Yes & Yes & Yes & Yes \\
\hline Observations & 4929 & 4926 & 4929 & 4926 & 4933 & 4922 & 4933 & 4922 & 4947 & 4908 & 4947 & 4908 \\
\hline Adj. $\mathrm{R}^{2}$ & 0.121 & 0.025 & 0.452 & 0.314 & 0.094 & 0.011 & 0.403 & 0.325 & 0.129 & 0.015 & 0.397 & 0.355 \\
\hline
\end{tabular}

This table reports the results of FE estimation of equation (9) on the impact of CGQ on leverage in firms with high and low levels of stock liquidity, based on whether the firms' stock liquidity position is above or below the median. The independent variable is CGQ measured by CG index following the Horwath CG report. The dependent variable is leverage, which is defined as the ratio of total debt to book value of assets (BL) and market value of assets (ML). The definition of variables is provided in Table $1 . t$ statistics are given in parentheses. *, **, *** represent significant at the $10 \%, 5 \%$, and $1 \%$ levels, respectively. 
Table 8

Analysis of economic significance

\begin{tabular}{|c|c|c|c|c|c|}
\hline Panel A & $\Delta \mathrm{QS}(1)$ & Coefficient of QS (2) & $(1 * 2=3)$ & Average leverage (4) & Economic significance (3/4) \\
\hline $\mathrm{BL}$ & 0.06 & 0.655 & 0.0393 & 0.36 & 0.1092 \\
\hline ML & 0.06 & 0.676 & 0.0406 & 0.27 & 0.1502 \\
\hline Panel B & $\Delta$ Amihud (1) & Coefficient of Amihud (2) & $(1 * 2=3)$ & Average leverage (4) & Economic significance (3/4) \\
\hline $\mathrm{BL}$ & 3.91 & 0.006 & 0.0235 & 0.36 & 0.0652 \\
\hline ML & 3.91 & 0.011 & 0.0430 & 0.27 & 0.1593 \\
\hline Panel C & $\Delta \mathrm{LM}(1)$ & Coefficient of LM (2) & $(1 * 2=3)$ & Average leverage (4) & Economic significance (3/4) \\
\hline $\mathrm{BL}$ & 5.98 & 0.007 & 0.0419 & 0.36 & 0.1163 \\
\hline ML & 5.98 & 0.009 & 0.0538 & 0.27 & 0.1993 \\
\hline Panel D & $\Delta \mathrm{CG}$ index (1) & Coefficient of CG index (2) & $(1 * 2=3)$ & Average leverage (4) & Economic significance (3/4) \\
\hline $\mathrm{BL}$ & 7 & -0.0018 & -0.0126 & 0.36 & -0.0350 \\
\hline ML & 7 & -0.0340 & -0.2380 & 0.27 & -0.8815 \\
\hline Panel E & $\Delta$ CG index*QS (1) & Coefficient of CG index*QS (2) & $(1 * 2=3)$ & Average leverage (4) & Economic significance (5) \\
\hline $\mathrm{BL}$ & 11 & -0.001 & -0.011 & 0.36 & -0.0306 \\
\hline ML & 11 & -0.002 & -0.022 & 0.27 & -0.0815 \\
\hline Panel F & $\Delta$ CG index*Amihud (1) & Coefficient of CG index*Amihud (2) & $(1 * 2=3)$ & Average leverage (4) & Economic significance (5) \\
\hline $\mathrm{BL}$ & 11 & -0.002 & -0.022 & 0.36 & -0.0611 \\
\hline ML & 11 & -0.003 & -0.033 & 0.27 & -0.1222 \\
\hline Panel G & $\Delta \mathrm{CG}$ index*LM (1) & Coefficient of CG index*LM (2) & $(1 * 2=3)$ & Average leverage (4) & Economic significance (5) \\
\hline $\mathrm{BL}$ & 11 & -0.002 & -0.022 & 0.36 & -0.0611 \\
\hline ML & 11 & -0.003 & -0.033 & 0.27 & -0.1222 \\
\hline
\end{tabular}


Table 9

Estimates of exogenous shock to liquidity on stock liquidity-leverage relation (H1)

\begin{tabular}{|c|c|c|c|c|c|c|}
\hline & QS & & Amihud & & LM & \\
\hline & $\begin{array}{l}\Delta \mathrm{BL} \\
(1)\end{array}$ & $\begin{array}{l}\Delta \mathrm{ML} \\
(2)\end{array}$ & $\begin{array}{l}\Delta \mathrm{BL} \\
\text { (3) }\end{array}$ & $\begin{array}{l}\Delta \mathrm{ML} \\
\text { (4) }\end{array}$ & $\begin{array}{l}\Delta \mathrm{BL} \\
(5)\end{array}$ & $\begin{array}{l}\Delta \mathrm{ML} \\
(6)\end{array}$ \\
\hline$\Delta \mathrm{QS}$ & $\begin{array}{l}0.952 * * * \\
(3.32)\end{array}$ & $\begin{array}{l}0.840 * * * \\
(4.12)\end{array}$ & & & & \\
\hline$\Delta$ Amihud & & & $\begin{array}{l}0.009 * \\
(1.75)\end{array}$ & $\begin{array}{l}0.010 * * * \\
(2.69)\end{array}$ & & \\
\hline$\Delta \mathrm{LM}$ & & & & & $\begin{array}{l}0.007 * * \\
(2.26)\end{array}$ & $\begin{array}{l}0.004^{* *} \\
(2.09)\end{array}$ \\
\hline Intercept & $\begin{array}{l}0.005 \\
(0.58)\end{array}$ & $\begin{array}{l}0.003 \\
(0.47)\end{array}$ & $\begin{array}{l}0.008 \\
(0.82)\end{array}$ & $\begin{array}{l}0.005 \\
(0.79)\end{array}$ & $\begin{array}{l}0.007 \\
(0.74)\end{array}$ & $\begin{array}{l}0.004 \\
(0.67)\end{array}$ \\
\hline$\Delta$ control variables & Yes & Yes & Yes & Yes & Yes & Yes \\
\hline Observations & 662 & 662 & 662 & 662 & 662 & 662 \\
\hline Adj. $\mathrm{R}^{2}$ & 0.168 & 0.250 & 0.158 & 0.239 & 0.161 & 0.236 \\
\hline
\end{tabular}

This table reports the results on addressing endogeneity in the stock liquidity-leverage relation using an exogenous shock to liquidity (Eq. 10). $\Delta$ denotes the change in each variable from the financial year prior to the switch to broker anonymity to the financial year after the switch (i.e., 2004 to 2006). The independent variable is stock liquidity, which is measured by QS, Amihud and LM. The dependent variable is leverage, which is defined as the ratio of total debt to book value of assets (BL) and market value of assets (ML). The coefficients of control variables are not reported in the interests of brevity. The definition of variables is provided in Table $1 . t$ statistics are given in parentheses. *, **, *** represent significant at the10\%, $5 \%$, and $1 \%$ levels, respectively. 
Table 10

GMM estimates of stock liquidity-leverage (H1) and CGQ-leverage (H2) relations

\begin{tabular}{|c|c|c|c|c|c|c|c|c|}
\hline & QS & & Amihud & & $\mathrm{LM}$ & & CGQ & \\
\hline & $\begin{array}{l}\mathrm{BL} \\
(1)\end{array}$ & $\begin{array}{l}\text { ML } \\
\text { (2) }\end{array}$ & $\begin{array}{l}\text { BL } \\
\text { (3) }\end{array}$ & $\begin{array}{l}\text { ML } \\
\text { (4) }\end{array}$ & $\begin{array}{l}\text { BL } \\
\text { (5) }\end{array}$ & $\begin{array}{l}\text { ML } \\
\text { (6) }\end{array}$ & $\begin{array}{l}\mathrm{BL} \\
\text { (7) }\end{array}$ & $\begin{array}{l}\text { ML } \\
\text { (8) }\end{array}$ \\
\hline Lagged leverage & $\begin{array}{l}0.384 * * * \\
(14.84)\end{array}$ & $\begin{array}{l}0.230 * * * \\
(10.34)\end{array}$ & $\begin{array}{l}0.573 * * * \\
(31.18)\end{array}$ & $\begin{array}{l}0.496^{* * *} \\
(27.98)\end{array}$ & $\begin{array}{l}0.388 * * * \\
(15.04)\end{array}$ & $\begin{array}{l}0.224 * * * \\
(9.96)\end{array}$ & $\begin{array}{l}0.120^{* * *} \\
(5.70)\end{array}$ & $\begin{array}{l}0.260 * * * \\
(11.69)\end{array}$ \\
\hline QS & $\begin{array}{l}0.447^{* * * *} \\
(4.41)\end{array}$ & $\begin{array}{l}0.432 * * * \\
(4.95)\end{array}$ & & & & & & \\
\hline Amihud & & & $\begin{array}{l}0.007^{* * *} \\
(4.42)\end{array}$ & $\begin{array}{l}0.006^{* * *} \\
(3.88)\end{array}$ & & & & \\
\hline LM & & & & & $\begin{array}{l}0.005^{* * *} \\
(4.54)\end{array}$ & $\begin{array}{l}0.006^{* * * *} \\
(5.82)\end{array}$ & & \\
\hline CG index & & & & & & & $\begin{array}{l}-0.005^{* * *} \\
(-2.80)\end{array}$ & $\begin{array}{l}-0.004^{* * *} \\
(-3.39)\end{array}$ \\
\hline Intercept & $\begin{array}{l}-0.817 * * * \\
(-5.03)\end{array}$ & $\begin{array}{l}-1.676^{* * *} \\
(-11.04)\end{array}$ & $\begin{array}{l}-0.221^{* * *} \\
(-2.66)\end{array}$ & $\begin{array}{l}-0.844 * * * \\
(-11.31)\end{array}$ & $\begin{array}{l}-0.847^{* * *} \\
(-5.09)\end{array}$ & $\begin{array}{l}-1.739 * * * \\
(-11.08)\end{array}$ & $\begin{array}{l}-1.359 * * * \\
(-7.44)\end{array}$ & $\begin{array}{l}-1.552 * * * \\
(-10.82)\end{array}$ \\
\hline Control variables & Yes & Yes & Yes & Yes & Yes & Yes & Yes & Yes \\
\hline Year effect & Yes & Yes & Yes & Yes & Yes & Yes & Yes & Yes \\
\hline AR (1) & $\begin{array}{l}-9.77^{* * *} \\
{[0.000]}\end{array}$ & $\begin{array}{l}-9.09 * * * \\
{[0.000]}\end{array}$ & $\begin{array}{l}-11.24 * * * \\
{[0.000]}\end{array}$ & $\begin{array}{l}-11.95 * * * \\
{[0.000]}\end{array}$ & $\begin{array}{l}-9.80 * * * \\
{[0.000]}\end{array}$ & $\begin{array}{l}-9.07^{* * *} \\
{[0.000]}\end{array}$ & $\begin{array}{l}-6.43^{* * *} \\
{[0.000]}\end{array}$ & $\begin{array}{l}-9.47 * * * \\
{[0.000]}\end{array}$ \\
\hline AR (2) & $\begin{array}{l}0.96 \\
{[0.338]}\end{array}$ & $\begin{array}{l}-1.40 \\
{[0.162]}\end{array}$ & $\begin{array}{l}1.21 \\
{[0.228]}\end{array}$ & $\begin{array}{l}-0.47 \\
{[0.639]}\end{array}$ & $\begin{array}{l}1.03 \\
{[0.303]}\end{array}$ & $\begin{array}{l}-1.37 \\
{[0.170]}\end{array}$ & $\begin{array}{l}-1.49 \\
{[0.144]}\end{array}$ & $\begin{array}{l}-1.28 \\
{[0.199]}\end{array}$ \\
\hline Hensen J-statistics & $\begin{array}{l}853.46 \\
{[0.239]}\end{array}$ & $\begin{array}{l}856.66 \\
{[0.216]}\end{array}$ & $\begin{array}{l}953.51 \\
{[0.517]}\end{array}$ & $\begin{array}{l}989.68 \\
{[0.219]}\end{array}$ & $\begin{array}{l}846.25 \\
{[0.296]}\end{array}$ & $\begin{array}{l}853.8 \\
{[0.237]}\end{array}$ & $\begin{array}{l}858.67 \\
0.286\end{array}$ & $\begin{array}{l}846.55 \\
0.294\end{array}$ \\
\hline Observations & 8545 & 8545 & 8545 & 8545 & 8545 & 8545 & 8545 & 8545 \\
\hline No of instruments & 849 & 849 & 849 & 849 & 849 & 849 & 860 & 849 \\
\hline No of firms & 1150 & 1150 & 1150 & 1150 & 1150 & 1150 & 1150 & 1150 \\
\hline
\end{tabular}

This table reports the results on addressing endogeneity in the stock liquidity-leverage relation (Eq. 6, Columns 1-6) and CGQ-leverage relation (Eq. 7, Columns 7-8) using two-step system GMM. The independent variables include lagged leverage, stock liquidity (QS, Amihud and LM) and CGQ measured by CG index following the Horwath CG report. The dependent variable is leverage, which is defined as the ratio of total debt to book value of assets (BL) and market value of assets (ML). The coefficients of control variables are not reported in the interests of brevity. The definition of variables is provided in Table 1. $t$ statistics are given in parentheses. *, **, *** represent significant at the $10 \%, 5 \%$, and $1 \%$ levels, respectively. 
Table 11

Regression estimates with changes in the variables (H1 \& H2)

\begin{tabular}{|c|c|c|c|c|c|c|}
\hline & QS & & Amihud & & LM & \\
\hline & $\begin{array}{l}\Delta \mathrm{BL} \\
(1)\end{array}$ & $\begin{array}{l}\Delta \mathrm{ML} \\
(2)\end{array}$ & $\begin{array}{l}\Delta \mathrm{BL} \\
(3)\end{array}$ & $\begin{array}{l}\Delta \mathrm{ML} \\
(4)\end{array}$ & $\begin{array}{l}\Delta \mathrm{BL} \\
(5)\end{array}$ & $\begin{array}{l}\Delta \mathrm{ML} \\
(6)\end{array}$ \\
\hline$\Delta \mathrm{QS}$ & $\begin{array}{l}0.299 * * * \\
(6.90)\end{array}$ & $\begin{array}{l}0.306^{* * * *} \\
(8.88)\end{array}$ & & & & \\
\hline$\Delta$ Amihud & & & $\begin{array}{l}0.003^{* * *} \\
(3.15)\end{array}$ & $\begin{array}{l}0.003^{* * * *} \\
(3.20)\end{array}$ & & \\
\hline$\Delta \mathrm{LM}$ & & & & & $\begin{array}{l}0.003^{* * *} \\
(6.60)\end{array}$ & $\begin{array}{l}0.004^{* * * *} \\
(9.60)\end{array}$ \\
\hline$\Delta \mathrm{CG}$ index & $\begin{array}{l}-0.001 \\
(-1.08)\end{array}$ & $\begin{array}{l}-0.001 * * \\
(-2.40)\end{array}$ & $\begin{array}{l}-0.001 \\
(-1.08)\end{array}$ & $\begin{array}{l}-0.001^{* *} \\
(-2.42)\end{array}$ & $\begin{array}{l}-0.001 \\
(-1.00)\end{array}$ & $\begin{array}{l}-0.001^{* *} \\
(-2.28)\end{array}$ \\
\hline Intercept & $\begin{array}{l}-0.002 \\
(-0.92)\end{array}$ & $\begin{array}{l}-0.005^{* * *} \\
(-3.25)\end{array}$ & $\begin{array}{l}-0.002 \\
(-0.78)\end{array}$ & $\begin{array}{l}-0.005^{* * *} \\
(-3.07)\end{array}$ & $\begin{array}{l}-0.002 \\
(-1.02)\end{array}$ & $\begin{array}{l}-0.006^{* * *} \\
(-3.42)\end{array}$ \\
\hline $\begin{array}{l}\Delta \text { Control } \\
\text { variables }\end{array}$ & Yes & Yes & Yes & Yes & Yes & Yes \\
\hline Year effect & Yes & Yes & Yes & Yes & Yes & Yes \\
\hline Observations & 8405 & 8405 & 8405 & 8405 & 8405 & 8405 \\
\hline Adj. $\mathrm{R}^{2}$ & 0.169 & 0.369 & 0.165 & 0.364 & 0.169 & 0.370 \\
\hline
\end{tabular}

This table reports the results of FE estimation of equation (8) on the effect of stock liquidity and corporate governance on leverage using changes (first difference) in both the dependent (i.e., leverage) and independent variables (i.e., QS, Amihud, LM and CG index). The coefficients of control variables are not reported in the interests of brevity. The definition of variables is provided in Table 1. $t$ statistics are given in parentheses. *, **, *** represent significant at the $10 \%, 5 \%$, and $1 \%$ levels, respectively. 